\title{
STRATIGRAPHIC AND TIME-STRATIGRAPHIC CROSS SECTIONS: A NORTH-SOUTH TRANSECT FROM NEAR THE UINTA MOUNTAIN AXIS ACROSS THE BASIN AND RANGE TRANSITION ZONE TO THE WESTERN MARGIN OF THE SAN RAFAEL SWELL, UTAH
}

By

\author{
Douglas A. Sprinkel
}

\section{INTRODUCTION}

The U.S. Geological Survey is conducting multidisciplinary geologic studies of several sedimentary basins in the United States under the auspices of the U.S. Geological Survey's Evolution of Sedimentary Basins Program. This report is the Utah Geological Survey's contribution to the study of the Uinta-Piceance Basin.

These cross sections incorporate published stratigraphic information and reinterpret data obtained from selected exploration boreholes to illustrate the stratigraphic relationships of rocks in an area that extends south of the Crawford Mountains, across the western projection of the Uinta Mountains and Uinta Basin, and across the San Pitch Mountains and Wasatch Plateau to the northwest side of the San Rafael Swell (figs. 1 and 2). Johnson and Johnson (1991a, 1991b), and Franczyk (1991) published cross sections of rocks in other parts of the Uinta-Piceance Basin area.

The purpose of these cross sections is to illustrate the changes in lithofacies, thickness, and nomenclature of Phanerozoic stratigraphic units from a north-south perspective. None of the stratigraphic units were palinspastically restored for the cross sections.

\section{CONSTRUCTION OF THE STRATIGRAPHIC CROSS SECTIONS}

\section{DISCUSSION OF THE DATA POINTS}

The cross sections were constructed using 31 data points consisting of 29 exploratory wells and two surface- control points (table 1, appendix). The wells were selected because of their location, depth of penetration, and amount of stratigraphic section preserved in the well. Published geologic maps and stratigraphic reports were used to augment subsurface control and determine the regional extent, thickness, and nomenclature of stratigraphic units. The depths of individual wells used in these sections range from $1,088 \mathrm{ft}(332 \mathrm{~m})$ to $21,845 \mathrm{ft}(6,658 \mathrm{~m})$.

Gamma ray, sonic, formation-density-compensated neutron, and resistivity logs were used to determine subsurface contacts or formation tops, and to correlate stratigraphic units. For some wells (mostly wells in Utah, Juab and Sanpete counties), mud logs were available to aid in lithologic identification of stratigraphic units; the sonic-density and neutron-density cross-plot methods (Schlumberger, 1972, 1984) were used to determine the lithologies of critical stratigraphic intervals. No cuttings or cores from the wells within the study area were examined.

\section{DISCUSSION OF THE TIME-STRATIGRAPHIC CROSS SECTION}

The time scale of Haq and Van Eysinga (1987) was used to construct the time-stratigraphic cross section, and the stratigraphic units are shown in their best fit. The section line crosses or parallels many significant geologic features, such as the Sevier orogenic belt (Armstrong, 1968), areas of diapirism (Witkind, 1982), and the Utah hingeline (Stokes, 1976) (figs. 3 and 4). These geologic features produced rapid lithofacies changes between closely spaced wells or juxtaposed depositional facies within a borehole, creating special problems for construction of the sections. 
The time-stratigraphic relationships within the CharlestonNebo thrust plate (data points 8-11, 13, and 14) proved the most difficult to represent because several thrust faults were found in some wells. The most significant thrust fault was penetrated by the Placid Oil Company Daniels Land \#1 well (data point 8). In that well, the Charleston thrust fault placed allochthonous strata (represented by thicker depositional facies of the Upper Mississippian to Middle Pennsylvanian Manning Canyon Shale and Lower Pennsylvanian to Lower Permian Oquirrh Formation) over autochthonous strata (represented by Mesozoic strata and thinner depositional facies of the Middle Pennsylvanian to Lower Permian Weber Sandstone).

To graphically represent the stratigraphic relationships within the Charleston-Nebo thrust plate on the timestratigraphic cross section, a solid line with barbs marks the thrust-fault boundary at the base of the allochthon. A dashed line with barbs marks the thrust-fault boundary at the top of the footwall. Solid time lines are used to indicate the allochthonous strata found within the allochthon and the autochthonous strata found below the allochthon. Autochthonous strata found between the thrust-fault boundaries are indicated by dashed time lines. No special graphic representation was needed to portray repeated stratigraphic units found in wells located within the zone of imbricate thrust faults and post-thrusting diapirism (data points 15-25).

\section{DISCUSSION OF THE STRATIGRAPHIC CROSS SECTION}

The datum for the stratigraphic cross section is the $\mathrm{J}-2$ unconformity (Pipiringos and O'Sullivan, 1978) at the top of the Gypsum Spring Member of the Twin Creek Limestone. Where the Gypsum Spring Member of the Twin Creek Limestone is not preserved, the $\mathrm{J}-2$ unconformity truncates the J-1 unconformity and is located at the top of the Nugget Sandstone and Navajo Sandstone (Pipiringos and O'Sullivan, 1978). Most wells used to construct the cross section penetrate the J-2 unconformity. The unconformity at the base of the North Horn Formation was arbitrarily used as a local datum for part of the Charleston-Nebo thrust plate (data points 9-11).

The thicknesses of stratigraphic units were determined from geophysical well logs and nearby outcrops. The reader should be aware that for some units (particularly Upper Cretaceous and Tertiary units in the Wasatch Plateau area) the thicknesses determined from well logs may disagree with nearby outcrop data. The thicknesses of stratigraphic units that were not penetrated by the wells or whose contacts were undeterminable from well logs were extrapolated between data points and constrained by regional data. The erratic variations in thickness of some units were regarded as duplication or attenuation of stratigraphic section attributable to structural mechanisms. Where stratigraphic units are repeated within a well, an average thickness was used in the cross section. Normal thickness variations result from regional changes in depositional patterns. Thicknesses of units determined from well logs are summarized in tables 2 through 5. The thicknesses of units listed in the Appendix are considered to be apparent stratigraphic thicknesses because no dipmeter data were found for the wells used in the study to calculate true thicknesses.

\section{DISCUSSION OF STRATIGRAPHIC PROBLEMS AND INTERPRETATIONS}

The following section briefly describes the problems encountered and interpretations used during the construction of these cross sections. Some of the stratigraphic units are discussed in regional terms, but this report does not cover the entire Phanerozoic history or the paleogeographic settings of these rocks.

\section{CAMBRIAN STRATIGRAPHY}

Lochman-Balk $(1972,1976)$ shows that the basal Cambrian quartzite units were time-transgressive from Early Cambrian in the west to Late Cambrian in the east, unconformably onlapping Precambrian strata. The section line for this report generally parallels the time-transgressive shoreline where the basal Cambrian rocks are thought to be mostly Middle Cambrian.

Overlying Cambrian strata can be divided into a thinner eastern depositional facies (data points 26-31) and a thicker western depositional facies (data points 15-25) in central Utah (Juab, Sanpete, and Emery counties). The thinner depositional facies consists of the Ophir Shale and Maxfield Limestone (Middle Cambrian), and Lynch Dolomite (Upper Cambrian)(Hintze, 1988). The thicker depositional facies consists of the Teutonic Limestone, Dagmar Dolomite, Bluebird Dolomite, and Cole Canyon Dolomite (Middle Cambrian), and the Opex Formation and Ajax Dolomite (Upper Cambrian)(Hintze, 1988). The location where the Cambrian strata thickens is not well known, but it is probably somewhere within the zone of Cretaceous imbricate thrusting and post-thrust diapirism (data points 15-25). Elsewhere along the section line, the thinner depositional facies of the Middle and Upper Cambrian units are the dominant rock types.

A regional unconformity marks the top of the Cambrian strata. The Maxfield Limestone and Lynch Dolomite are not preserved (Bromfield and others, 1970) along the western projection of the Uinta Mountains (data point 7). The location of the erosional edge of these units is uncertain, but it probably underlies the Charleston and Absaroka thrust faults south and north of the Uinta Mountains. 


\section{ORDOVICIAN STRATIGRAPHY}

Ordovician rocks are missing in most of the stratigraphic cross section. According to Hintze (1988), either they were never deposited or they were deposited and subsequently removed by widespread erosion in Early Devonian time. Ordovician rocks were penetrated by one well (data point 1) on the Absaroka thrust plate. Stratigraphic nomenclature applied to the Upper Ordovician strata (in the subsurface and in outcrop) in this part of Utah is inconsistent and confusing. Typically, the Upper Ordovician rocks in Wyoming are assigned to the Bighorn Dolomite, whereas the time-equivalent rocks in north-central Utah are assigned to the Fish Haven Dolomite (Foster, 1972). The contact between the two units is located just east of the Idaho-Wyoming border (Armstrong and Oriel, 1965; Oriel and Platt, 1980). Similarly, Ott (1980) mapped Fish Haven Dolomite on the hanging wall of the Crawford thrust fault in the southern Crawford Mountains of Utah; the Bighorn Dolomite is the name used for similar rocks penetrated by wells to the east in Wyoming. However, the Bighorn Dolomite has been used to designate the Upper Ordovician strata penetrated by wells located on the hanging wall of the Absaroka thrust fault within the Utah part of the Sevier orogenic belt (Lamerson, 1982; West and Lewis, 1982). Although the term Fish Haven Dolomite is generally used to designate the Upper Ordovician rocks in northern Utah, the term Bighorn Dolomite is used in this study to designate the Upper Ordovician strata preserved on the hanging wall of the Absaroka thrust fault.

\section{DEVONIAN STRATIGRAPHY}

The oldest Devonian rocks found along the section line are Late Devonian age and follow the regional paleogeographic patterns of Rigby and Clark (1962), Baars (1972), Sandberg and others (1982), and Hintze (1988). On the western margin of the San Rafael Swell and Wasatch Plateau (data points 12, 26-31), the Upper Devonian is represented by the Elbert Formation and Ouray Limestone. The Pinyon Peak Limestone and Upper Devonian and Lower Mississippian Fitchville Formation are found west and north of the Wasatch Plateau along the section line (data points 7-11, 13-25). Even though the Upper Devonian formations were probably deposited under similar shallow-water conditions (Sandberg and others, 1982), the lateral continuity of these formations and the nature and location of the contact between these formations can not be conclusively demonstrated along the section line because of the lack of detailed subsurface control. For this study, the contact between the rocks of the San Rafael Swell and Wasatch Plateau (Elbert Formation and Ouray Limestone), and the rocks of similar age west of the Wasatch Plateau (Pinyon Peak Limestone and Fitchville Formation) was tentatively placed between the Hansen Oil Moroni 1AX and Phillips USA-E 1 wells (data points 25 and 26).
The age of the rocks of the Fitchville Formation is Late Devonian to Early Mississippian (Gutschick and others, 1980; Sandberg and Gutschick, 1979; Sandberg and others, 1982). The Devonian-Mississippian boundary within the Fitchville Formation is unconformable (Greenhalgh, 1980; Sandberg and others, 1982), but the unconformity is not shown on these cross sections.

\section{MISSISSIPPIAN STRATIGRAPHY}

Mississippian rocks within the Utah part of the Absaroka plate (data points 1-6) were assigned to the Lodgepole Limestone and Brazer Dolomite by Sandberg and others (1982) and Hintze (1988). Geophysical logs from the Amoco Island Ranching D-1 well (data point 1) indicate that the same interval of Mississippian rocks is found in the well and can be separated into a lower limestone and an upper dolomite. This subdivision is consistent with that of surface exposures of Lodgepole Limestone and Brazer Dolomite in the nearby Crawford Mountains (Sando and others, 1959; Sando and Dutro, 1960; Ott, 1980). Mississippian rocks that crop out near the western projection of the Uinta Mountains were assigned to the Fitchville Formation, Gardison Limestone, Deseret Limestone, and the Brazer Dolomite by Gutschick and others (1980).

Except for the Manning Canyon Shale (Poole and Sandberg, 1977), the top of the Mississippian section is unconformable with overlying strata along the section line. In central Utah (data points 13-25), the unconformity generally has been eroded down to the Deseret Limestone; the overlying Humbug Formation is locally preserved.

\section{PENNSYLVANIAN STRATIGRAPHY}

The section line generally crosses the stable shelf (the area east of the hingeline) that was present during Pennsylvanian time (Welsh and Bissell, 1979). However, thicker basinal depositional facies of the Oquirrh Formation (Bissell, 1962) are exposed in the hanging wall of the Charleston-Nebo thrust plate (data points 8-11) where they have been displaced eastward over the thinner shelf depositional facies (Baker, 1976). This relationship is visible in the Placid Oil Company well, Daniels Land \#1 (data point 8), which penetrated the Oquirrh Formation. In this well, the Charleston thrust fault placed the Upper Mississippian to Lower Pennsylvanian Manning Canyon Shale over Jurassic rocks at $10,920 \mathrm{ft}(3,328 \mathrm{~m})$ (appendix). Below the thrust, the well penetrated an uninterrupted stratigraphic sequence and reached the Middle Pennsylvanian to Lower Permian Weber Sandstone at the bottom of the well. This relationship implies that the thinner shelf depositional facies (including the Round Valley Limestone and Weber Sandstone) underlie most of the Charleston-Nebo thrust plate, and that the boundary between the shelf depositional facies and the thicker basinal rocks lies to the west. South 
of the Charleston-Nebo thrust plate (data points 12-31), there are no Pennsylvanian rocks because of preWolfcampian erosion of the Emery paleotopographic high in central Utah (Welsh and Bissell, 1979).

\section{PERMIAN STRATIGRAPHY}

The Emery paleotopographic high dominated depositional patterns in central Utah during most of the Permian Period. Much of the Permian section is missing on the western margin of the San Rafael Swell. The wells that penetrated rocks below the Permian section on the western margin of the San Rafael Swell (data points 29,30) revealed that the White Rim Sandstone rests on the Mississippian Redwall Limestone. However, immediately westward under the Wasatch Plateau, rocks older than the White Rim Sandstone may be present in the subsurface (Hintze, 1988). According to an interpretation of the Phillips USA-E 1 well (data point 26) in Hintze (1988, chart 63, p. 169), the Elephant Canyon Formation consists of a sequence of dolomite, sandstone, and evaporite beds underlying the Toroweap Formation. However, there is little subsurface control and no paleontologic data to conclusively assign the beds that lie between the Toroweap Formation and the Redwall Limestone to the Elephant Canyon Formation. The use of the term Elephant Canyon Formation is under debate (Loope and others, 1990; Sanderson and Verville, 1990; Baars, 1991). The rocks identified as the Elephant Canyon Formation in the Phillips well do compare reasonably well with part of the lithologic sequence of the Toroweap Formation described by Rawson and Turner-Peterson (1979) in northern Arizona. Thus, the Permian sequence that underlies the Wasatch Plateau and surrounding area to the west is herein assigned to the Toroweap Formation.

The Black Box Dolomite (formerly Kaibab Limestone of Gilluly and Reeside, 1928) was named by Welsh and others (1979) for the Permian carbonate rocks deposited on the Emery paleotopographic high. The northern extent of Black Box Dolomite deposition is uncertain, but it probably intertongues with the Park City Formation under the CharlestonNebo thrust plate.

Along the section line, the rocks of Permian age on the hanging wall of the Absaroka thrust fault consist of the Park City and Phosphoria Formations. The Park City and Phosphoria Formations represent a sequence of rocks that records the intertonguing relationship between shallow-water marine sedimentation and upwelling deeper-water marine sedimentation along a carbonate shelf (Peterson, 1980; Hintze, 1993). For this study, the Park City and Phosphoria Formations are graphically represented as one unit.

\section{TRIASSIC STRATIGRAPHY}

Rocks of the Triassic System found along the section line generally consist of Lower and Upper Triassic marine and nonmarine deposits separated by the $\operatorname{Tr}-3$ unconformity (Pipiringos and O'Sullivan, 1978; Hintze, 1993). Most of the Middle Triassic rocks are missing. However, the lowermost beds of the Ankareh Formation and the uppermost beds of the Moenkopi Formation may be remnants of lower Middle Triassic rocks (Hintze, 1988).

The Lower and Middle(?) Triassic Moenkopi Formation of central Utah (data points 12-31) can be divided into several members (Irwin, 1971; Blakey, 1974; Hintze, 1988) and laterally grades northward into the Woodside Shale, Thaynes Formation, and possibly the lower part of the Ankareh Formation (data points 1-11). The individual members of the Moenkopi Formation were identified on geophysical logs and included on the stratigraphic cross section, but space constraints prohibited drawing the time lines on the time-stratigraphic cross section. Upper Triassic rocks found along the section line in central Utah (data points 12-31) include beds of the Chinle Formation. Similar to the underlying beds of the Moenkopi Formation, the Chinle Formation grades laterally northward into the Ankareh Formation.

According to Pipiringos and O'Sullivan (1978), the Tr-3 unconformity is an easily recognized regional surface in the Triassic. The unconformable surface separates the basal Upper Triassic Moss Back Member of the Chinle Formation from the underlying Lower Triassic Moenkopi Formation in central Utah, and the basal Upper Triassic Gartra Member of the Chinle Formation from the underlying Lower Triassic Moenkopi Formation in northeastern Utah (Poole and Stewart, 1964; Pipiringos and O'Sullivan, 1978). In northern Utah, the Tr-3 unconformity separates the basal Upper Triassic Gartra(?) Member of the Ankareh Formation from the underlying Lower Triassic Mahogany Member of the Ankareh Formation as mapped by Crittenden and others (1966) and Bromfield and Crittenden (1971). The stratigraphic relationship between the Moss Back and Gartra Members of the Chinle Formation in central and northeastern Utah is fairly well understood (Poole and Stewart, 1964). However, the stratigraphic relationship between the Gartra Member of the Chinle Formation of Poole and Stewart (1964) and the Gartra(?) Member of the Ankareh Formation as mapped by Crittenden and others (1966) and Bromfield and Crittenden (1971) is less well understood, and no definitive work has been published to clarify it. Thus, the Gartra(?) Member of the Ankareh Formation may not be a time-correlative unit to the Moss Back or Gartra Members of the Chinle Formation as shown on the timestratigraphic cross section.

\section{JURASSIC STRATIGRAPHY}

The Middle Jurassic Arapien Shale (following the nomenclature of Witkind and Hardy, 1983), which consists of mudstone, limestone, and evaporite beds, was thought to overlie the Navajo Sandstone (Spieker, 1946; Hardy, 1952; 
Imlay, 1967, 1980). Hardy (1952) conducted a detailed stratigraphic study of the Arapien Shale and noted that the predominately mudstone and evaporite section was underlain by a thick sequence of carbonate rocks. Hardy (1952) assigned these carbonate rocks to the lower part of the Arapien Shale, designating them as Unit A. Imlay (1967) suggested that the lower carbonate section of the Arapien Shale was probably correlative with beds of the lower part of the Twin Creek Limestone, and that the overlying mudstone and evaporite section of the Arapien Shale was correlative with the upper part of the Twin Creek Limestone. Sprinkel (1982) and Sprinkel and Waanders (1984), using palynologic and other subsurface data, correlated this sequence of lower carbonate rocks (which persistently separate the Navajo Sandstone from the predominately mudstone and evaporite section of the Arapien Shale) with Imlay's (1967, 1980) lower five members (Gypsum Spring, Sliderock, Rich, Boundary Ridge, and Watton Canyon Members) of the Twin Creek Limestone of northern Utah. Only the upper two members (Leeds Creek and Giraffe Creek Members) of the Twin Creek Limestone were correlative with the Arapien Shale (Sprinkel and Waanders, 1984), as shown between data points 7 and 8 .

The areal extent of the Arapien Shale was formerly regarded as limited to eastern Juab, Sanpete, and western Sevier Counties (Spieker, 1946; Hardy, 1952). However, Sprinkel and Waanders (1984) suggested that the Arapien Shale may extend as far north as the southern flank of the Uinta Mountains, and that the lithofacies boundary between the Arapien Shale and the upper two members of the Twin Creek Limestone must be located near the western projection of the Uinta Mountains. The location of this hypothesized stratigraphic relationship is based on my interpretation of the Arapien Shale and Twin Creek Limestone lithofacies along and near the section line. Rocks of the Arapien Shale are believed to overlie the Twin Creek Limestone in both the hanging wall and footwall of the Charleston-Nebo thrust plate. The Arapien Shale in the hanging wall was penetrated in two wells located near Indianola (data points 13 and 14) and crops out at Red Canyon (Biek, 1991) and Thistle (Witkind and Page, 1983). The Leeds Creek Member of the Twin Creek Limestone was identified at Monks Hollow by Imlay (1967); he described it as being similar to the upper shaley part of the Arapien Shale. Similarly, Baker (1976) mapped the only complete section of Twin Creek Limestone in the area surrounding Monks Hollow. Although he did not map its individual members, Baker (1976) described the Twin Creek Limestone as having an upper shaley part and a lower limey part. I believe that the beds formerly identified as the Leeds Creek Member at Monks Hollow are beds of the Arapien Shale, based on their distinctively drab appearance (characteristic of the Arapien Shale), their high percentage of mudstone, and the presence of gypsum. The northernmost occurrence of Arapien Shale in the cross section is thought to be located on the footwall of the Charleston-Nebo thrust plate in the Placid Oil Company Daniels Land \#1 well (data point 8 ). In this well, $473 \mathrm{ft}$ ( $144 \mathrm{~m}$ )(appendix) of dark-gray mudstone, limestone, and anhydrite beds assigned to the Arapien Shale are structurally overlain by the Charleston thrust fault and rest on beds identified as the Watton Canyon Member of the Twin Creek Limestone.

There is a great deal of variation of bed thickness in the Jurassic Arapien Shale. In central Utah (data points 12-26), it ranges from about $1,000 \mathrm{ft}(305 \mathrm{~m})$ thick under the Wasatch Plateau to about $11,000 \mathrm{ft}(3,353 \mathrm{~m})$ thick near the axis of the Sanpete-Sevier Valley anticline (Gilliland, 1963). Along the section line, the thickness of the Arapien Shale averages $3,500 \mathrm{ft}(1,067 \mathrm{~m})$. I believe the maximum depositional thickness of the Arapien Shale is only about 2,000 to $3,000 \mathrm{ft}$ (610 to $914 \mathrm{~m}$ ) and is less than that suggested by Standlee (1982). In making his thickness estimates, Standlee (1982) included the Twin Creek Limestone with the Arapien Shale, in contrast to Sprinkel (1982). Standlee (1982) also used two wells, the Dixel Gunnison State \#1 (data point 21) and the Chevron Chriss Canyon Unit \#1 (NE1/4NW1/4 sec. 33, T. 16 S., R. 1 E., Sanpete County) to estimate depositional thickness. Both of these wells are in the zone of imbricate thrusting and postthrusting diapirism where it is difficult to rule out structural thickening of the Arapien Shale because of compressional folding, imbricate thrust splays, and diapirism. Lawton (1985) estimated that the thickness of the Middle Jurassic section in central Utah may have been doubled by thrusting. However, it is difficult to rule out concurrent diapiric movement of the Arapien Shale during thrusting events. The thicker sections of Arapien Shale are, therefore, attributed to tectonic thickening by thrusting and folding during the Sevier orogeny and post-thrusting mobilization of Arapien strata by diapirism (Standlee, 1982; Witkind, 1982; Lawton, 1985; Villien and Kligfield, 1986; Willis, 1986, 1988).

The age of the Twist Gulch Formation, which overlies the Arapien Shale (data points 12, 18-26), is uncertain. Imlay (1980) considered it to be lower to middle Callovian, based on its stratigraphic position and its similarity to the Preuss Sandstone. In addition, beds exposed in the upper $177 \mathrm{ft}$ of the Twist Gulch Formation near Salina Canyon (Willis, 1986) are similar to beds of the Curtis Formation exposed on the San Rafael Swell, which Imlay (1980) considered to be upper middle Callovian. However, Villien and Kligfield (1986) found Early Cretaceous palynomorphs in rocks mapped as Twist Gulch Formation by Hunt (1950) and Hardy and Zeller (1953) along Chicken Creek in the Gunnison Plateau. Auby (1991) assigned rocks that were previously included in the upper part of the Twist Gulch Formation by Hunt (1950) and Hardy and Zeller (1953) to the Lower Cretaceous Cedar Mountain Formation. The rocks described by Villien and Kligfield (1986) probably belong to the Cedar Mountain Formation, not the Twist Gulch Formation. Thus, the Twist Gulch Formation shown on the cross section is similar to the work of Imlay (1980). 
The age of the Morrison Formation is considered to be Late Jurassic by Imlay (1980). Laser fusion argon-argon dating of rock samples collected in the Morrison Formation also indicates that the Morrison Formation is Late Jurassic age (Kowallis and Christensen, 1991; Kowallis and others, 1992). The Late Jurassic age of the Morrison Formation revises an earlier report by Kowallis and Heaton (1987), which suggested that the Morrison Formation (Brushy Basin Member) may be Early Cretaceous age.

\section{CRETACEOUS STRATIGRAPHY}

Lower and Upper Cretaceous rocks along the section line generally parallel the migrating shorelines of the Western Interior, as shown in regional paleogeographic reconstructions (McGookey and others, 1972; Ryer and McPhillips, 1983; Franczyk and others, 1992). However, much of the present-day distribution of Cretaceous rocks along the section line is the result of the tectonic influence of the Sevier orogenic belt. In the northern part of the cross section (data points 1-7), the Lower Cretaceous is represented by the Kelvin Formation and the lower part of the Aspen Shale; the Upper Cretaceous is represented by the upper part of the Aspen Shale, Frontier Formation, and lower part of the Evanston Formation (Hale, 1960a, 1960b; Crittenden, 1963; Ryer, 1977; Jacobson and Nichols, 1982; Nichols and Jacobson, 1982a, 1982b; Nichols and others, 1982; Bryant and Nichols, 1988; Bryant, 1990; Franczyk and others, 1992). Along the section line, both Lower and Upper Cretaceous rocks are present on the hanging wall of the Absaroka thrust plate, whereas only Lower Cretaceous rocks are present on the footwall.

All of the Lower Cretaceous rocks and most of the Upper Cretaceous rocks are missing on the hanging wall of the Charleston-Nebo thrust plate (data points 8-11). However, Lower and Upper Cretaceous rocks are believed to underlie the leading edge of the Charleston-Nebo thrust plate (W.A. Yonkee, oral commun., 1990). Although well data has not confirmed that Cretaceous units underlie the leading edge of the Charleston-Nebo thrust fault, the stratigraphic section (if preserved intact) is probably represented by rocks of the Dakota Sandstone, Mancos Shale, and Mesaverde Group (Franczyk and others, 1992). Until well data becomes available, the detailed stratigraphic relationships among the Cretaceous units on the footwall of the Charleston-Nebo thrust fault and the time-stratigraphic equivalent beds of the Absaroka thrust plate remain uncertain.

Lower Cretaceous stratigraphy in central Utah (data points 12-26) has been entangled in problems of nomenclature. Speiker (1946) originally assigned outcrops of variegated beds that rest on the Middle Jurassic Twist Gulch Formation and underlie the Upper Cretaceous Sanpete Formation to the Morrison(?) Formation. Spieker's (1946) Morrison(?) Formation consists of two distinctive and easily recognizable lithostratigraphic units: a lower variegated mudstone unit and an upper conglomerate unit (Witkind and others, 1986). The lower variegated mudstone unit also includes beds of siltstone, pebbly sandstone, some limestone, and distinctive limestone nodules. The upper conglomerate unit is interbedded with sandstone and mudstone, and contains distinctive green quartzite clasts (Sprinkel and others, 1992). Formal abandonment of the Morrison(?) Formation was first recommended by Witkind and others (1986). They reassigned beds of the lower variegated mudstone unit to the Cedar Mountain Formation based on lithologic similarity (particularly the distinctive limestone nodules) to the Cedar Mountain Formation exposed in the San Rafael Swell (Stokes, 1944, 1952); however, the authors disagreed on the reassignment of the upper conglomerate unit. Co-author L.E. Standlee believed that the upper conglomerate unit was an unrecognized lithofacies of the Cedar Mountain Formation, whereas co-authors I.J. Witkind and K.F. Maley believed that it should be reassigned to the overlying Indianola Group (Witkind and others, 1986). Similarly, Weiss and Roche (1988) assigned the lower variegated mudstone unit to the Cedar Mountain Formation and proposed that the upper conglomerate unit be a new unnamed basal unit of the Indianola Group. In addition, Weiss (1990) recently mapped the variegated mudstone beds as part of the Cedar Mountain Formation and the overlying conglomerate unit as the basal conglomerate of the Indianola Group. Weiss (1990) did not formally propose a name for the upper conglomerate unit because he believed additional work was needed to determine its regional extent. In the same publication that the Weiss and Roche (1988) paper appeared, Schwans (1988) defined a new formation, the Pigeon Creek Formation, for the lower variegated mudstone unit and the upper conglomerate unit of Spieker's (1946) Morrison(?) Formation. Schwans (1988) believed that these rocks were restricted to central Utah and represented a significant unconformity-bounded sequence of the early Cordilleran foreland basin. Schwans (1988) also recognized the distinctive lithologic boundary between the lower variegated mudstone unit (lower Pigeon Creek member) and the upper conglomerate unit (upper Pigeon Creek member). Recent work in the extreme southeastern part of the Gunnison Plateau by Sprinkel and others (1992) corroborated the work of Witkind and others (1986), Weiss and Roche (1988), and Weiss (1990) by assigning the lower variegated mudstone unit to the Cedar Mountain Formation and designating the upper conglomerate unit as an unnamed (synorogenic clastic unit) conglomerate. For this report, I correlated the Cedar Mountain Formation of the San Rafael Swell region (data points 29-31) into central Utah (data points 12, 19-26) using geophysical and mud logs; however, the overlying unnamed conglomerate unit does not extend eastward beyond the central part of the Wasatch Plateau (data point 26). Thus, in this report, the name Cedar Mountain Formation is assigned in the restricted sense (Witkind and others, 1986; Weiss and Roche, 1988) and as mapped by Weiss (1990) and Auby 
(1991). Also in this report, the overlying unnamed conglomerate is considered to be a discrete mappable unit and is not assigned to either the underlying Cedar Mountain Formation or the overlying Indianola Group (Sprinkel and others, 1992). The Cedar Mountain Formation is considered to be Aptian-Albian in age (Tschudy and others, 1984; Witkind and others, 1986) and the unnamed conglomerate is Aptian to middle Albian in age (Witkind and others, 1986; Sprinkel and others, 1992).

During the Late Cretaceous period in central Utah (data points 12-31), clastic marine and nonmarine rocks were deposited within a foreland basin (Lawton, 1982; Franczyk and others, 1992). The pattern of sedimentation within the basin generally was controlled by its proximity to the emerging Sevier orogenic belt and eustatic changes of sea level (Lawton, 1982; Franczyk and others, 1992). The stratigraphic section is dominated by a marine depositional facies in the lower part that grades upward into (and interfingers with) nonmarine depositional facies in the upper part (Lawton, 1982, 1983, 1985, 1986; Fouch and others, 1982, 1983; Franczyk and others, 1992). The vertical succession from marine to nonmarine depositional facies is also duplicated laterally as the Cretaceous seas transgressed westward and then retreated in response to the eastward-advancing thrust belt and associated fluvial sedimentation (Franczyk and others, 1992).

Upper Cretaceous rocks along the eastern part of the cross section in central Utah (data points 12, 26-31) are the Dakota Sandstone, Mancos Shale, and Mesaverde Group (Franczyk and others, 1992). These formations are exposed on the east side of the Wasatch Plateau (Witkind and others, 1987; Witkind, 1988) and are informally referred to in this report as the eastern depositional facies. To the west (data points 13-25), Upper Cretaceous rocks include the Sanpete Formation, Allen Valley Shale, Funk Valley Formation, and Sixmile Canyon Formation of the Indianola Group (Spieker, 1949; Weiss, 1990; Franczyk and others, 1992). Rocks of the Indianola Group are coarser grained than the time-equivalent rocks (Dakota Sandstone, Mancos Shale, and Mesaverde Group) exposed to the east and the group is informally referred to in this report as the western depositional facies. Correlation of the eastern and western depositional facies is similar to the work of Lawton (1982, 1983, 1985, 1986), Fouch and others (1982, 1983), and Franczyk and others (1992).

The lithologic changes between the eastern and western depositional facies underlies the west-central part of the Wasatch Plateau. Near the center of the Wasatch Plateau, the Phillips USA-E 1 well (data point 26) penetrated Upper Cretaceous rocks that, from geophysical logs and mudlogs, appear to be similar to rocks of both the eastern and western depositional facies. The strata assigned to the Dakota Sandstone and Emery Sandstone Member of the Mancos Shale that were found in the Phillips USA-E 1 well are similar to that of the western depositional facies. The Dakota
Sandstone is typically 50 to $150 \mathrm{ft}$ (15 to $46 \mathrm{~m}$ ) thick and contains carbonaceous material. Strata of the Dakota Sandstone found in the above-mentioned well is much thicker and coarser. Similarly, the strata assigned to the Emery Sandstone Member of the Mancos Shale found in the Phillips USA-E 1 well are much thicker and coarser, and contain more thin coal beds than do Emery strata exposed to the east. However, the Tununk and Blue Gate Members of the Mancos Shale found in the well contain thick beds of marine shale typical of the Upper Cretaceous rocks exposed on the east side of the Wasatch Plateau. Although the Upper Cretaceous rocks found in the Phillips USA-E 1 well are a thicker and coarser sequence of rocks (characteristics of the western depositional facies), nomenclature typical of rocks exposed on the east side of the Wasatch Plateau is recommended for this part of the Wasatch Plateau (Lawton, oral commun., 1990).

\section{TERTIARY STRATIGRAPHY}

This part of the report focuses on the Tertiary rocks located along the section line south of the Uinta Mountains (data points 9-25). The North Horn Formation is discussed in the Tertiary section of this report even though the lower part of the North Horn Formation can be as old as Late Cretaceous (Maastrichtian) in the Wasatch Plateau area (data points 12, 26) (Fouch, 1983, fig. 2; Franczyk and others, 1992). However, the lower part of the North Horn Formation in the San Pitch Mountains and the surrounding area (data points 13-25), and in the western Uinta basin area (data points 9-11) may be considerably younger (late Paleocene) (Fouch, 1983, fig. 2; Bryant and others, 1989a; Franczyk and others, 1992).

Along the part of the section line that is within the western Uinta basin, the Tertiary rocks belong to the North Horn Formation, the Flagstaff Member of the Green River Formation, the Colton Formation, the Green River Formation, and the Duchesne River Formation (Fouch, 1976; Bryant and others, 1989; Franczyk and others, 1992). This stratigraphic sequence rests unconformably on part of the allochthonous upper Paleozoic strata of the Charleston-Nebo thrust plate (Baker, 1976). Three wells in the western Uinta basin (data points 9-11) penetrated a thick section of predominately fluvial and lacustrine strata, which also unconformably overlies allochthonous Paleozoic strata. Although the stratigraphic section probably includes beds of the Flagstaff Member of the Green River Formation and the Colton Formation, a detailed correlation chart that included the nearby exposures mapped by Bryant and others (1989) was not attempted because mud $\log$ sere unavailable and not all of the geophysical logs were run over the entire stratigraphic sequence in the wells located along the section line. Future work using well cuttings or mud logs from these wells (data points 9-11) will probably reveal the carbonate beds that are characteristic of the Flagstaff Member of the Green River 
Formation and that separate the red clastic beds of the overlying Colton Formation and underlying North Horn Formation. For this report, I tentatively separated a lower sandier lithofacies from an upper muddier lithofacies using the available geophysical logs. The North Horn Formation represents the sandier lithofacies and the Green River Formation represents the muddier lithofacies.

The revised nomenclature of the lower part of the Tertiary System proposed by Fouch (1976) applies only to the central and western Uinta Basin. Paleocene and Eocene rocks in central Utah (data points 12-26) include part of the North Horn Formation and the Flagstaff Limestone (locally the Flagstaff Formation); Eocene rocks in this area include the Colton Formation, the Green River Formation, and the Crazy Hollow Formation (Spieker, 1946, 1949; Fouch and others, 1982, 1983; Weiss, 1982; Lawton, 1985; Willis, 1986, 1988; Marcantel and Weiss, 1968; Franczyk and others, 1992). Depositional environments and intertonguing relationships of these units are similar to those rocks in the western Uinta Basin (Franczyk and others, 1992).

The Flagstaff Limestone exposed on the Wasatch Plateau is mostly limestone (as the name implies) and is separated into three members (Stanley and Collinson, 1979). South and west of the Wasatch Plateau, the Flagstaff Limestone loses its predominantly limestone lithology and laterally grades to sandstone, conglomerate, and mudstone with some interbedded limestone. In the areas south and west of the plateau, the name Flagstaff Formation is used to show that this unit is a mixture of lithologies (Willis, 1986, 1988, 1991). The age of the Flagstaff Limestone is Paleocene to early Eocene (LaRocque, 1960).

An unconformity marks the base of the North Horn Formation, but the contacts between the North Horn Formation, Flagstaff Limestone, Colton Formation, and Green River Formation are conformable (Fouch and others, 1983). However, locally each of these units may unconformably rest on Cretaceous or older strata. Local paleohighs or islands in central Utah were created by thrusting (Standlee, 1982), diapirism within the Arapien Shale (Witkind, 1982), or both (Lawton, 1985; Villien and Kligfield, 1986; Willis, 1986, 1988; Mattox, 1992; Weiss, 1990). These paleohighs probably controlled deposition of the North Horn Formation and possibly the Flagstaff Limestone (Witkind, 1982; Lawton, 1985; Mattox, 1992; Weiss, 1990). Sporadic episodes of diapiric movement in the Arapien Shale locally controlled the deposition of the post-Flagstaff strata (Witkind, 1982; Witkind and Page, 1984; Lawton, 1985; Willis, 1986, 1988; Mattox, 1992; Weiss, 1990).

The predominant late Eocene and Oligocene rocks in the cross section are pyroclastic and volcaniclastic rocks, although sedimentary rocks of the Duchesne River Formation are also present (Bryant and others, 1989a). The Keetley Volcanics are exposed near the west end of the Uinta Mountains (data point 7); the Goldens Ranch and Moroni Formations crop out to the south in central Utah (data 15-20)
(Bryant and others, 1989a). Witkind and Marvin (1989) described the evolution of nomenclature for the Goldens Ranch and Moroni Formations, and discussed the radiometric age and lithologic similarities of the two units. They concluded that the two units are identical lithologically, but they recommended that both formation names be retained because they were unable to confirm physical continuity between the two units and both names were well established in the literature. They recommended that the use of the term Goldens Ranch Formation be restricted to areas surrounding Juab Valley (eastern Juab County) and that use of the term Moroni Formation be restricted to areas surrounding Sanpete Valley (western Sanpete County).

\section{QUATERNARY STRATIGRAPHY}

The section line crosses a variety of Quaternary deposits that are not represented on the cross section because these deposits are generally thin, localized, and were not mapped in sufficient detail. They include alluvial, colluvial, eolian, and mass-wasting deposits. However, in a few areas along the section line (data points 18-20, 22-24) where the Quaternary units were mapped in detail, units of the Lake Bonneville Group, the alluvium in southern Juab Valley (Oviatt, 1992), and the alluvium in Sanpete Valley (Weiss, 1990) are shown on the cross section.

\section{ACKNOWLEDGMENTS}

I wish to thank the geologists who generously took time to share their knowledge of regional stratigraphic and structural relationships, which helped solve many of the problems encountered during the construction of these cross sections. Discussions with Utah Geological Survey geologists Hellmut Doelling, Lehi Hintze, Alec Keith, Michael Ross, Grant Willis, and Adolf Yonkee of Weber State University, and Tim Lawton of New Mexico State University made this project an exhilarating exercise. I also thank Floyd Moulton and Frank $P$. Turner who provided mudlogs and other well information for several wells used in the cross section. I am deeply indebted to the reviewers, Sam Johnson and Tom Fouch (U.S. Geological Survey), Hellmut Doelling, and Lehi Hintze. Their comments greatly improved the quality of the cross sections and manuscript. Finally, I wish to thank Sam Johnson for all of his help and advice, and M. Lee Allison (Utah Geological Survey) for allowing me to shed the surly bonds of "administrivia" to undertake and complete this project.

\section{REFERENCES CITED}

Armstrong, F.C., and Oriel, S.S., 1965, Tectonic development of Idaho-Wyoming thrust belt: American Association of Petroleum Geologists Bulletin, v. 49, no. 11, p. 1847-1866. 
Armstrong, R.L., 1968, Sevier orogenic belt in Nevada and Utah: Geological Society of America Bulletin, v. 79, no. 4, p. 429-458.

Auby, W.L., 1991, Provisional geologic map of the Levan quadrangle, Juab County, Utah: Utah Geological Survey Map 135,13 p., scale 1:24,000.

Baars, D.L., 1972, Devonian System, in Mallory, W.M., ed., Geologic atlas of the Rocky Mountain region: Rocky Mountain Association of Geologists, p. 90-99.

Baars, D.L., 1991, The Elephant Canyon Formation-for the last time: The Mountain Geologist, v. 28, no. 1, p. 1-2.

Baker, A.A., 1976, Geologic map of the west half of the Strawberry Valley quadrangle, Utah: U.S. Geological Survey Miscellaneous Investigations Map I-931, scale 1:63,360.

Banks, R.L., 1991, Provisional geologic map of Fountain Green North quadrangle, Sanpete and Juab counties, Utah: Utah Geological Survey Map 134, 21 p., scale 1:24,000.

Biek, R.F., 1991, Provisional geologic map of the Nephi quadrangle, Juab County, Utah: Utah Geological Survey Map 137, 21 p., scale 1:24,000.

Bissell, H.J., 1962, Pennsylvanian-Permian Oquirrh Basin of Utah: Brigham Young University Geology Studies, v. 9, part 1, p. 26-49.

Blakey, R.C., 1974, Stratigraphic and depositional analysis of the Moenkopi Formation, southeastern Utah: Utah Geological and Mineral Survey Bulletin 104, 81 p.

Bryant, Bruce, 1991, Geologic map of the Salt Lake City $30^{\prime} \times 60^{\prime}$ quadrangle, north-central Utah, and Uinta County, Wyoming: U.S. Geological Survey Miscellaneous Investigations Map I-1944, scale 1:100,000.

Bryant, Bruce, Naesser, C.W., Marvin, R.F., and Mehnert, H.H, 1989a, Upper Cretaceous and Paleogene sedimentary rocks and isotopic ages of Paleogene tuffs, Uinta basin, Utah: U.S. Geological Survey Bulletin 1787-J, 22 p.

1989b, Ages of late Paleogene and Neogene tuffs and the beginning of rapid regional extension, eastern boundary of the Basin and Range province near Salt Lake City, Utah: U.S. Geological Survey Bulletin 1787-K, 12 p.

Bryant, Bruce, and Nichols, D.J., 1988, Late Mesozoic and early Tertiary reactivation of an ancient crustal boundary along the Uinta trend and its interaction with the Sevier orogenic belt in Schmidt, C.J., and Perry, W.J., Jr., eds., Interaction of the Rocky Mountain foreland and the Cordilleran thrust belt: Geological Society of America Memoir 171, p. $411-430$.

Bromfield, C.S., Baker, A.A., and Crittenden, M.D., Jr., 1970, Geologic map of the Heber quadrangle, Wasatch and Summit counties, Utah: U.S. Geological Survey Geologic Quadrangle Map GQ-864, scale 1:24,000.

Bromfield, C.S., and Crittenden, M.D., Jr., 1971, Geologic map of the Park City East quadrangle, Summit and Wasatch counties, Utah: U.S. Geological Survey Geologic Quadrangle Map GQ-852, scale 1:24,000.

Crittenden, M.D., Jr., 1963, Emendation of the Kelvin Formation and Morrison(?) Formation near Salt Lake City, Utah: U.S. Geological Survey Professional Paper 475-B, p. B95-B98.

1974, Regional extent and age of thrusts near Rockport Reservoir and relation to possible exploration targets in northern Utah: American Association of Petroleum Geologists Bulletin, v. 58, no. 12, p. 2428-2435.
Crittenden, M.D., Jr., Calkins, F.C., and Sharp, B.J., 1966, Geologic map of the Park City West quadrangle, Utah: U.S. Geological Survey Geologic Quadrangle Map GQ-535, scale $1: 24,000$.

Foster, N.H., 1972, Ordovician System, in Mallory, W.M., ed., Geologic atlas of the Rocky Mountain region: Rocky Mountain Association of Geologists, p. 76-85.

Fouch, T.D., 1976, Revisions of the lower part of the Tertiary System in the central and western Uinta basin, Utah: U.S. Geological Survey Bulletin 1405-C, 7 p.

Fouch, T.D., Lawton, T.F., Nichols, D.J., Cashion, W.B., and Cobban, W.A., 1982, Chart showing preliminary correlation of major Albian to middle Eocene rock units from the Sanpete Valley in central Utah to the Book Cliffs in eastern Utah, in Nielson, D.L., ed., Overthrust Belt of Utah: Utah Geological Association Publication 10, p. 267-272.

1983, Patterns and timing of synorogenic sedimentation in Upper Cretaceous rocks of central and northeast Utah, in Reynolds, M.W., and Dolly, E.D., eds., Mesozoic Paleogeography of west-central United States, Society of Economic Paleontologists and Mineralogists: Rocky Mountain Paleogeography Symposium 2, p. 305-336.

Franczyk, K.J., 1991, Stratigraphic and time-stratigraphic cross sections of Phanerozoic rocks along line $\mathrm{C}-\mathrm{C}^{\prime}$, Uinta and Piceance basin area, southern Uinta Mountains to northern Henry Mountains, Utah: U.S. Geological Survey Miscellaneous Investigations Map I-2184-C.

Franczyk, K.J., Fouch, T.D., Johnson, R.C., Molenaar, C.M., and Cobban, W.A., 1992, Cretaceous and Tertiary paleogeographic reconstructions for the Uinta-Piceance basin study area, Colorado and Utah: U.S. Geological Survey Bulletin $1787-\mathrm{Q}, 37 \mathrm{p}$.

Gilliland, W.N., 1963, Sanpete-Sevier Valley anticline of central Utah: Geological society of America Bulletin, v. 74, no. 2, p. 115-123.

Gilluly, J., 1929, Geology and oil and gas prospects of part of the San Rafael Swell, Utah: U.S. Geological Survey Bulletin 806-C, p. 69-130.

Gilluly. J., and Reeside, J.B., Jr., 1928, Sedimentary rocks of the San Rafael Swell and some adjacent areas in eastern Utah: U.S. Geological Survey Professional Paper 150, p. 61-110.

Greenhalgh, B.R., 1980, The Fitchville Formation: a study of biostratigraphy and depositional environments in west-central Utah County, Utah: Brigham Young University Geology Studies, v. 27, part 1, p. 9-29.

Gutschick, R.C., Sandberg, C.A., and Sando, W.J., 1980, Mississippian shelf margin and carbonate platform from Montana to Nevada, in Fouch, T.D., and Magathan, E.R., eds., Paleozoic paleogeography of the west-central United States: Society of Economic Paleontologists and Mineralogists, Rocky Mountain Section, Rocky Mountain Paleogeography Symposium 1, June 1980, Denver, CO, p. 111-128.

Hale, L.A., 1960a, Frontier Formation-Coalville, Utah and nearby areas of Wyoming and Colorado, in McGookey, D.P., and Miller, D.N., Jr., eds., Overthrust belt of southwestern Wyoming and adjacent areas: Wyoming Geological Association 15th Annual Field Conference Guidebook, p. 137-146. 1960b, Annotations to accompany Cretaceous correlation chart, in McGookey, D.P., and Miller, D.N., Jr., eds., Overthrust Belt of southwestern Wyoming and adjacent Areas: 
Wyoming Geological Association 15th Annual Field Conference Guidebook, p. 131-135.

Haq, B.U., and Van Eysinga, F.W.B., 1987, Geologic Time Table: Amsterdam, Elsevier Science Publishers B.V., 1 chart.

Hardy, C.T., 1952, Eastern Sevier Valley, Sevier and Sanpete counties, Utah: Utah Geological and Mineral Survey Bulletin 43, $98 \mathrm{p}$.

Hardy, C.T., and Zeller, H.D., 1953, Geology of the west-central part of the Gunnison Plateau, Utah: Geological Society of America Bulletin, v. 64, no. 11, p. 1261-1278.

Hintze, L.F., 1988, Geologic History of Utah: Brigham Young University Geology Studies Special Publication 7, 202 p. (Reprinted with minor revisions July, 1993).

Hunt, R.E., 1950, Geology of the northern part of the Gunnison Plateau: Columbus, Ohio State University, Ph.D. dissertation, $267 \mathrm{p}$.

Imlay, R.W., 1967, Twin Creek Limestone (Jurassic) in the western interior of the United States: U.S. Geological Survey Professional Paper 540, 105 p.

1980, Jurassic paleobiogeography of the conterminous United States in its continental setting: U.S. Geological Survey Professional Paper 1062, 134 p.

Irwin. C.D., 1971, Stratigraphic analysis of upper Permian and lower Triassic strata in southern Utah: American Association of Petroleum Geologists Bulletin, v. 55, no. 11, p. 1976-2007.

Jacobson, S.R., and Nichols, D.J., 1982. Palynological dating of syntectonic units in the Utah/Wyoming thrust belt: The Evanston Formation, Echo Canyon Conglomerate, and Little Muddy Creek Conglomerate, in Powers, R.B., ed., Geologic studies of the Cordilleran thrust belt: Rocky Mountain Association of Geologists, v. 2, p. 735-750.

Jefferson. W.S., 1982, Structural and stratigraphic relations of Upper Cretaceous to lower Tertiary orogenic sediments of the Cedar Hills, Utah, in Nielson, D.L., ed., Overthrust Belt of Utah: Utah Geological Association Publication 10, p. $65-80$.

Johnson, R.C., and Johnson, S.Y., 1991, Stratigraphic and timestratigraphic cross sections of Phanerozoic rocks along line B-B', Uinta and Piceance basin area, west-central Uinta basin, Utah, to eastern Piceance basin, Colorado: U.S. Geological Survey Miscellaneous Investigations Map I-2184-B.

Johnson, S.Y., and Johnson, R.C., 1991, Stratigraphic and timestratigraphic cross sections of Phanerozoic rocks along line $A-A^{\prime}$, Uinta and Piceance basins area-Eagle Basin, Colorado, to eastern Basin and Range, Utah: U.S. Geological Survey Miscellaneous Investigations Map I-2184-A.

Kowallis, B.J., and Christiansen, E.H., 1991, Correlation of altered volcanic ash in the Brushy Basin Member of the Morrison Formation, Colorado Plateau [abs.]: Geological Society of America Abstracts with Program, v. 23, no. 5, p. A295.

Kowallis, B.J., Christiansen, E.H., and Tingey, D.G., 1993, Volcanic ash layers in the Tidwell Member of the Upper Jurassic Morrison Formation: minimum age of the J-5 unconformity on the Colorado Plateau [abs.]: Geological Society of America Abstracts with Programs, v. 25, no. 6, p. A472-A473.

Kowallis, B.J., and Heaton, J.S., 1987, Fission-track dating of bentonites and bentonitic mudstones from the Morrison Formation in central Utah: Geology, v. 15, p. 1138-1142.
Lamerson, P.R., 1982, The Fossil Basin and its relationship to the Absaroka thrust system, Wyoming and Utah, in Powers, R.B., ed., Geologic studies of the Cordilleran thrust belt: Rocky Mountain Association of Geologists, v. 1, p. 279-340.

LaRocque, Aurele, 1960, Molluscan faunas of the Flagstaff formation of central Utah: Geological Society of America Memoir $78,100 \mathrm{p}$.

Lawton. T.F., 1982, Lithofacies correlations within the Upper Cretaceous Indianola Group, central Utah, in Nielson, D.L., ed., Overthrust Belt of Utah: Utah Geological Association Publication 10, p. 199-213.

1983, Late Cretaceous fluvial systems and the age of foreland uplifts in central Utah, in Lowell, J.D., ed., Rocky Mountain foreland basins and uplifts: Rocky Mountain Association of Geologists, p. 181-200.

1985, Style and timing of frontal structures, Thrust Belt, central Utah: American Association of Petroleum Geologists Bulletin, v. 69, no. 7, p. 1145-1159.

1986, Fluvial systems of Upper Cretaceous Mesaverde Group and Paleocene North Horn Formation, central Utaha record of transition from thin-skinned to thick-skinned eformation in the foreland region, in Peterson, J.A., ed., Paleotectonics and sedimentation in the Rocky Mountain region: American Association of Petroleum Geologists Memoir 41, p. 423-442.

Lochman-Balk, C., 1972, Cambrian System, in Mallory, W.M., ed., Geologic atlas of the Rocky Mountains region: Rocky Mountain Association of Petroleum Geologists, p. 60-75. 1976. Cambrian Section of the central Wasatch Mountains, in Hill, J.G., ed., Symposium on Geology of the Cordilleran Hingeline, p. 103-108.

Loope, D.B., Sanderson, G.A., and Verville, G.J., 1990, Abandonment of the Name "Elephant Canyon Formation" in southeastern Utah: physical and temporal implications: The Mountain Geologist, v. 27, no. 4, p. 119-130.

Mattox, S.R., 1987, Provisional geologic map of the Hell's Kitchen Canyon SE quadrangle, Sanpete County, Utah: Utah Geological and Mineral Survey Map 98, 17 p., scale 1:24,000. 1992, Provisional geologic map of the Gunnison quadrangle, Sanpete County, Utah: Utah Geological Survey Map 139,11 p., scale 1:24,000.

Marcantel, E.L.. and Weiss, M.P., 1968, Colton Formation (Eocene fluviatile) and associated lacustrine beds, Gunnison Plateau, central Utah: The Ohio Journal of Science, V. 68 , p. $40-49$.

Maughan, E.K., 1984, Geological setting and some geochemistry of petroleum source rocks in the Permian Phosphoria Formation, in Woodward, Jane, and others, eds., Hydrocarbon source rocks of the greater Rocky Mountain region: Rocky Mountain Association of Geologists, p. 281-294.

McGookey, D.P., Haun, J.D., Hale, L.A., Goodell, H.G., McCubbin, D.G., Weimer, R.J., and Wulf, G.R., 1972, Cretaceous System, in Mallory, W.M., ed., Geologic atlas of the Rocky Mountain region: Rocky Mountain Association of Geologists, p. 190-228.

Mullens, T.E., 1971, Reconnaissance study of the Wasatch, Evanston, and Echo Canyon Formations in part of northern Utah: U.S. Geological Survey Bulletin 1311-D, 31 p. 
Nichols, D.J., and Bryant, Bruce, 1986a, Palynology of the Current Creek and Mesaverde Formations in the Currant CreekDuchesne River area, Duchesne and Wasatch counties, Utah: U.S. Geological Survey Open-File Report 86-160, 7 p.

1986b, Palynologic data from Cretaceous and early Tertiary rocks in the Salt Lake $30^{\prime} \times 60^{\prime}$ quadrangle: U.S. Geological Survey Open-File Report 86-116, 18 p.

Nichols, D.J., and Jacobson, S.R., 1982a. Cretaceous biostratigraphy in the Wyoming Thrust Belt: The Mountain Geologist, v. 19, no. 3, p. 73-78.

1982b, Palynostratigraphic framework for the Cretaceous (Albian-Maestrichtian) of the Overthrust Belt of Utah and Wyoming: Palynology, v. 6, p. 119-147.

Nichols, D.J., Jacobson, S.R., and Tschudy, R.H., 1982, Cretaceous palynomorph biozones for the central and northern Rocky Mountain region of the United States, in Powers, R.B., ed., Geologic studies of the Cordilleran thrust belt: Rocky Mountain Association of Geologists, v. 2, p. 721-733.

Oriel, S.S., and Platt, L.B., 1980, Geologic Map of the Preston $1^{\circ} \times 2^{\circ}$ quadrangle, southeastern Idaho and western Wyoming: U.S. Geological Survey Miscellaneous Investigations Map I-1127, scale 1:250,000.

Ott, V.D., 1980, Geology of the Woodruff Narrows quadrangle, Utah-Wyoming: Brigham Young University Geology Studies, v. 27, part 2, p. 67-84.

Oviatt, C.G., 1992, Quaternary geology of the Scipio Valley area, Millard and Juab counties, Utah: Utah Geological Survey Special Studies 79, $16 \mathrm{p}$.

Peterson, J.A., 1980, Permian paleogeography and sedimentary provinces, west-central United States, in Fouch, T.D., and Magathan, E.R., eds., Paleozoic paleogeography of the west-central United States: Society of Economic Paleontologists and Mineralogists, Rocky Mountain Section, Rocky Mountain Paleogeography Symposium 1, June 1980. Denver, CO, p. 111-128.

Pipiringos, G.N., and Imlay, R.W., 1979, Lithology and subdivisions of the Jurassic Stump Formation in southeastern Idaho and adjoining areas: U.S. Geological Survey Professional Paper 1035-C, 25 p.

Pipiringos, G.N., and O'Sullivan, R.B., 1978, Principal unconformities in Triassic and Jurassic rocks, western interior United States-a preliminary survey: U.S. Geological Survey Professional Paper 1035-A, 29 p.

Poole, F.G., and Claypool, G.E., 1984, Petroleum source-rock potential and crude-oil correlation in the Great Basin, in Woodward, Jane, and others, eds., Hydrocarbon source rocks of the greater Rocky Mountain region: Rocky Mountain Association of Geologists, p. 179-229.

Poole, F.G., and Sandberg, C.A., 1977, Mississippian paleogeography and tectonics of the western United States, in Stewart, J.H., and others, eds., Paleozoic Paleogeography of the Western United States, Pacific Coast Paleogeography Symposium 1: Pacific Section, Society of Economic Paleontologists and Mineralogists, p. 67-85.

Poole, F.G., and Stewart, J.H., 1964, Chinle Formation and Glen Canyon Sandstone in northeastern Utah and northwestern Colorado: U.S. Geological Survey Professional Paper 501-D, p. D30-D39.
Rawson, R.R., and Turner-Peterson, C.E., 1979. Marine-carbonate, sabkha, and eolian facies transitions within the Permian Toroweap Formation, northern Arizona, in Baars, D.L., ed., Permianland: Four Corners Geological Society, 9th field conference Guidebook, p. 87-99.

Rigby, J.K., and Clark, D.L., 1962, Devonian and Mississippian Systems in central Utah: Brigham Young University Geology Studies, v. 9, part 1, p. 17-25.

Ryder, R.T., Fouch, T.D., and Elison, J.H., 1976, Early Tertiary sedimentation in the western Uinta basin, Utah: Geological Society of America Bulletin, v. 87, no. 4, p. 496-512.

Ryer, T.A., 1977, Age of Frontier Formation in north-central Utah: American Association of Petroleum Geologists Bulletin, v. 61, no. 1, p. 112-116.

Ryer, T.A., and McPhillips, Maureen, 1983, Early Late Cretaceous paleogeography of east/central Utah in Reynolds, M.W. and Dolly, E.D., eds., Mesozoic Paleogeography of the westcentral United States: Society of Economic Paleontologists and Mineralogists, Rocky Mountain Paleogeography Symposium 2, p. 253-272.

Sandberg, C.A., and Gutschick, R.C., 1979, Guide to conodont biostratigraphy of Upper Devonian and Mississippian rocks along the Wasatch front and Cordilleran hinge line, Utah, in Sandberg, C.A., and Clark, D.L., eds., Conodont biostratigraphy of the Great Basin and Rocky Mountains: Brigham Young University Geology Studies, v. 26, part 3, p. 107-134.

1984, Distribution, microfauna, and source-rock potential of Mississippian Delle Phosphatic Member of Woodman Formation and equivalents, Utah and adjacent states, in Woodward, Jane, and others, eds., Hydrocarbon source rocks of the greater Rocky Mountain region: Rocky Mountain Association of Geologists, p. 135-178.

Sandberg, C.A., Gutschick, R.C., Johnson, J.G., Poole, F.G., and Sando, W.J., 1982, Middle Devonian to Late Mississippian geologic history of the Overthrust Belt region, western U.S., in Powers, R.B., ed., Geologic studies of the Cordilleran thrust belt: Rocky Mountain Association of Geologists, v. 2, p. 691-719.

Sanderson, G.A., and Verville, G.J., 1990, Fusulinid zonation of the General Petroleum no. 45-5-G core. Emery County, Utah: The Mountain Geologist, v. 27, no. 4, p. 131-136.

Sando, W.J., and Dutro, J.T., Jr., 1960, Stratigraphy and coral zonation of the Madison Group and Brazer Dolomite in northeastern Utah, western Wyoming, and southwestern Montana, in McGookey, D.P.. and Miller, D.N., Jr., eds., Overthrust Belt of southwestern Wyoming and adjacent areas: Wyoming Geological Association 15th Annual Field Conference Guidebook, p. 117-126.

Sando, W.J., Dutro, J.T., Jr., and Gere, W.L., 1959, Brazer Dolomite (Mississippian), Randolph quadrangle, northeast Utah: American Association of Petroleum Geologists Bulletin, v. 43, no. 12 , p. $2741-2769$.

Schlumberger, 1972, Log Interpretation, volume 1, Principles: Schlumberger, New York, 113 p.

Schlumberger, 1984, Log Interpretation Chart:, Schlumberger, Well Services, U.S.A., 106 p.

Schwans, Peter, 1988, Depositional response of Pigeon Creek Formation, Utah, to initial fold-thrust belt deformation in a differentially subsiding foreland basin, in Schmidt, C.J., and 
Perry, W.J., Jr., eds., Interaction of the Rocky Mountain foreland and Cordilleran thrust belt: Geological Society of America Memoir 171, p. 531-556.

Spieker, E.M., 1946, Late Mesozoic and Early Cenozoic history of central Utah: U.S. Geological Survey Professional Paper 205-D, p. 117-161.

1949, The transition between the Colorado Plateau and the Great Basin in central Utah: Guidebook to the geology of Utah, no. 4, Utah Geological Society, 106 p.

Spreng, W.C., 1979, Upper Devonian and Lower Mississippian strata on the flanks of the western Uinta Mountains, Utah: Brigham Young University Geology Studies, v. 26, part 2, p. 67-79.

Sprinkel, D.A., 1982, Twin Creek Limestone-Arapien Shale relations in central Utah, in Nielson, D.L., ed., Overthrust Belt of Utah: Utah Geological Association Publication 10. p. 169-179.

Sprinkel, D.A., and Waanders, G.L., 1984, Correlation of Twin Creek Limestone with Arapien Shale in Arapien Embayment, Utah-Preliminary appraisal [abs.]: American Association of Petroleum Geologist Bulletin, v. 68, no. 7, p. 950.

Sprinkel, D.A., Weiss, M.P., and Fleming, R.W., 1992, Stratigraphic reinterpretation of a synorogenic unit of late Early Cretaceous age, Sevier orogenic belt, central Utah [abs.]: Geological Society of America Abstracts with Programs, v. 24 , no. 6, p. 63.

Standlee, L.A., 1982, Structure and stratigraphy of Jurassic rocks in central Utah: Their influence on tectonic development of the Cordilleran foreland thrust belt, in Powers, R.B., ed., Geologic studies of the Cordilleran thrust belt: Rocky Mountain Association of Geologists, p. 357-382.

Stanley, K.O., and Collinson. J.W., 1979, Depositional history of Paleocene-lower Eocene Flagstaff Limestone and coeval rocks, central Utah: American Association of Petroleum Geologists Bulletin, v. 63, no. 3, p. 311-323.

Stokes, W.L., 1944, Morrison and related deposits in and adjacent to the Colorado Plateau: Geological Society of America Bulletin, v. 55, no. 8, p. 951-992.

1952, Lower Cretaceous in Colorado Plateau: American Association of Petroleum Geologists Bulletin, v. 36, no. 9. p. 1766-1776.

1959, Jurassic rocks of the Wasatch Range and vicinity, in Williams, N.C., ed., Wasatch and Uinta Mountains: Intermountain Association of Petroleum Geologists, 10th Annual Field Conference guidebook, p. 109-114.

1972, Stratigraphic problems of the Triassic and Jurassic sedimentary rocks of central Utah, in Baer, J.L., and Callaghan, Eugene, eds., Plateau-Basin and Range transition zone: Utah Geological Association Publication 2, p. 21-27.

1976, What is the Wasatch line?, in Hill, J.G., ed., Symposium on geology of the Cordilleran hinge line: Rocky Mountain Association of Petroleum Geologists, p. 11-25. 1986, Geology of Utah: Utah Museum of Natural History Occasional Paper Number 6, and Utah Geological and Mineral Survey Miscellaneous Publication S, 280 p.

Sweet, W.C., 1979, Late Ordovician conodonts and biostratigraphy of the western Midcontinent Province: Brigham Young University Geology Studies, v. 26, part 3, p. 45-86.

Tisoncik, D.D., 1984, Regional lithostratigraphy of the Phosphoria Formation in the Overthrust Belt of Wyoming, Utah, and
Idaho, in Woodward, Jane, and óthers, eds., Hydrocarbon source rocks of the greater Rocky Mountain region: Rocky Mountain Association of Geologists, p. 295-320.

Tschudy, R.H., Tschudy, B.D., and Craig, L.C., 1984, Palynological evaluation of Cedar Mountain and Burro Canyon Formations, Colorado Plateau: U.S. Geological Survey Professional Paper 1281, 24 p.

Villien, Alain, and Kligfield, R.M., 1986, Thrusting and synorogenic sedimentation in central Utah, in Peterson, J.A., ed., Paleotectonics and sedimentation in the Rocky Mountain region: American Association of Petroleum Geologists Memoir 41, p. 281-306.

Weiss, M.P., 1982, Relation of the Crazy Hollow Formation to the Green River Formation, central Utah, in Nielson, D.L., ed., Overthrust Belt of Utah: Utah Geological Association Publication 10 , p. $285-289$.

1990, Geologic map of the Sterling 7-minute quadrangle, Sanpete County, Utah: Utah Geological and Mineral Survey Open-File Report 195, scale 1:24,000.

Weiss, M.P., and Roche, M.G., 1988, The Cedar Mountain Formation (Lower Cretaceous) in the Gunnison Plateau, central Utah, in Schmidt, C.J., and Perry, W.J., Jr., eds., Interaction of the Rocky Mountain foreland and Cordilleran thrust belt: Geological Society of America Memoir 171, p. 557- 569.

Welsh, J.E., and Bissell, H.J., 1979, The Mississippian and Pennsylvanian (Carboniferous) systems in the United States-Utah: U.S. Geological Survey Professional Paper 1110-M-DD, p. Y1-Y35.

Welsh, J.E., Stokes, W.L., and Wardlaw, B.R., 1979, Regional stratigraphic relationships of the Permian "Kaibab" or Black Box Dolomite of the Emery high, central Utah, in Baars, D.L., ed., Permianland: Four Corners Geological Society Guidebook, 9th Field Conference, p. 143-149.

West, Judy, and Lewis, Helen, 1982, Structure and palinspastic reconstruction of the Absaroka thrust. Anschutz Ranch area, Utah and Wyoming, in Powers, R.B., ed., Geologic studies of the Cordilleran thrust belt: Rocky Mountain Association of Geologists, v. 2, p. 633-639.

Willis, G.C., 1986, Geologic Map of the Salina quadrangle, Sevier County, Utah: Utah Geological and Mineral Survey Map 83, 20 p., scale 1:24,000.

1988, Geologic Map of the Aurora quadrangle, Sevier County, Utah: Utah Geological and Mineral Survey Map 112,21 p., scale 1:24,000.

1991, Geologic map of the Redmond Canyon quadrangle, Sanpete and Sevier counties, Utah: Utah Geological Survey Map 138, 17 p., scale 1:24,000.

Witkind, I.J., 1982, Salt diapirism in central Utah, in Nielson, D.L., ed., Overthrust Belt of Utah: Utah Geological Association Publication 10, p. 13-30.

1988, Geologic map of the Huntington $30^{\prime} \times 60^{\prime}$ quadrangle, Carbon, Emery, Grand, and Uintah counties, Utah: U.S. Geological Survey Miscellaneous Investigations Map I-1764, scale 1:100,000.

Witkind, I.J., and Hardy, C.T., 1983, The Arapien Shale of central Utah-A dilemma in stratigraphic nomenclature: U.S. Geological Survey Bulletin 1537-A, p. A5-A20.

Witkind, I.J., and Marvin, R.F., 1989, Significance of new potassium-argon ages from the Goldens Ranch and Moroni Formations, Sanpete-Sevier Valley area, central Utah: 
Geological Society of America Bulletin, v. 101, no. 4, p. 534-548.

Witkind, I.J., and Page, W.R., 1983, Geologic Map of the Thistle area, Utah County, Utah: Utah Geological and Mineral survey Map 69, scale 1:24,000.

1984, Origin and significance of the Wasatch and Valley Mountains monoclines, Sanpete/Sevier Valley area, central Utah: The Mountain Geologist, v. 21, no. 4, p. 143-156.
Witkind, I.J., Standlee, L.A., and Maley, K.F., 1986, Age and correlation of Cretaceous rocks previously assigned to the Morrison(?) Formation, Sanpete- Sevier Valley area, central Utah: U.S. Geological Survey Bulletin 1584, 9 p.

Witkind, I.J., Weiss, M.P., and Brown, T.L., 1987, Geologic map of the Manti $30^{\prime} \times 60^{\prime}$ quadrangle, Carbon, Emery, Juab, Sanpete, and Sevier counties, Utah: U.S. Geological Survey Miscellaneous Investigations Map I-1631, scale 1:100,000. 


\begin{abstract}
APPENDIX
The appendix contains the well information used to construct the cross sections. It gives the data-point number used to locate the well on the cross sections and in figure 4, the operator's name (OPERATOR), the well name (WELL NAME), the well location (by section, township, and range) (LOCATION), the county in which the well is located (COUNTY), the elevation of the Kelly Bushing (KB), and the total depth of penetration (TD). The appendix also lists names of formations identified in the well (FORMATION), the depth at which the formation was picked from well logs (TOPS), formation thickness

(THICK), and elevation of the formation relative to sea level (SUBSEA). All depths (negative numbers), elevations, and thicknesses are reported in feet.

The first formation listed for each well is the surface formation mapped at that location. It is indicated with a "TOP" of zero. Formations noted with the word "ESTIMATED" by the formation name or that may have a "TOP" of zero, indicate that I was uncertain about the exact location of the subsurface contact or that the well $\operatorname{logs}$ available to me were not run over that interval.
\end{abstract}


Table 1. Data points (DP) with references used to identify stratigraphic units and constrain stratigraphic nomenclature and ages

\begin{tabular}{|c|c|c|c|c|c|c|}
\hline Area & $\mathrm{DP}$ & Operator & Well Name & Location & County & References \\
\hline Absaroka thrust plate & $\begin{array}{l}1 \\
2 \\
3 \\
4 \\
5 \\
6\end{array}$ & $\begin{array}{l}\text { Amoco } \\
\text { Anschutz } \\
\text { American Quasar } \\
\text { American Quasar } \\
\text { Exxon } \\
\text { Amoco }\end{array}$ & $\begin{array}{l}\text { Island Ranching D-1 } \\
\text { Anschutz Ranch 3-1 } \\
\text { UPRR 27-1 } \\
\text { UPRR 35-1 } \\
\text { UPRR 9-1 } \\
\text { Rockport Reservoir 1 }\end{array}$ & $\begin{array}{l}\text { T. } 4 \text { N., R. } 7 \text { E., sec. } 14 \\
\text { T. } 3 \text { N., R. } 7 \text { E., sec. } 3 \\
\text { T. } 2 \text { N., R. } 6 \text { E., sec. } 27 \\
\text { T. } 2 \text { N., R. } 6 \text { E., sec. } 35 \\
\text { T. } 1 \text { N., R. } 6 \text { E., sec. } 9 \\
\text { T. } 1 \text { N., R. } 5 \text { E., sec. } 21\end{array}$ & $\begin{array}{l}\text { Summit } \\
\text { Summit } \\
\text { Summit } \\
\text { Summit } \\
\text { Summit } \\
\text { Summit }\end{array}$ & $\begin{array}{l}\text { Armstrong and Oriel, 1965; Baars, 1972; Crittenden, 1963, 1974; Foster, 1972; Gutschick and } \\
\text { others, 1980; Hale, 1960a, 1960b; Hintze, 1988; Imlay, 1967, 1980; Jacobson and Nichols, 1982; } \\
\text { Lamerson, 1982; Lochman-Balk, 1972,1976; Maughan, 1984; McGookey and others, 1972; } \\
\text { Mullens, 1971; Nichols and others, 1982; Nichols and Jacobson, 1982a, 1982b; Oriel and Platt, } \\
\text { 1980; Ott, 1980; Pipiringos and Imlay, 1979; Pipiringos and O'Sullivan, 1978; Poole and } \\
\text { Sandberg, 1977; Poole and Stewart, 1964; Ryer, 1977; Sandberg and others, 1982; Sando and } \\
\text { others, 1959; Sando and Dutro, 1960; Stokes, 1986; Sweet, 1979; Tisoncik, 1984; Welsh and } \\
\text { Bissell, 1979; West and Lewis, 1982 }\end{array}$ \\
\hline $\begin{array}{l}\text { Westem projection of } \\
\text { Uinta Mountains }\end{array}$ & 7 & & Surface control & & $\begin{array}{l}\text { Summit } \\
\text { and } \\
\text { Wasatch }\end{array}$ & $\begin{array}{l}\text { Bryant and Nichols, 1988; Bryant and others, 1989a, 1989b; Bromfield and Crittenden, 1971; } \\
\text { Bromfield and others, 1970; Crittenden and others, 1966; Franczyk and others, 1992; Hintze, } \\
\text { 1988; Spreng, 1979; Stokes, 1959, 1986 }\end{array}$ \\
\hline $\begin{array}{l}\text { Charleston - } \\
\text { Nebo thrust plate }\end{array}$ & $\begin{array}{l}8 \\
9 \\
10 \\
11 \\
13 \\
14\end{array}$ & $\begin{array}{l}\text { Placid } \\
\text { Amoco } \\
\text { Exxon } \\
\text { Exxon } \\
\text { Union Oil } \\
\text { Union Oil }\end{array}$ & $\begin{array}{l}\text { Daniels Land 1 } \\
\text { Strawberry River } 1 \\
\text { Strawberry Reservoir } 1 \\
\text { Buffalo Canyon Unit } 1 \\
\text { Federal 1-G-24 } \\
\text { Federal 1-J-9 }\end{array}$ & $\begin{array}{l}\text { T. } 5 \text { S., R. } 5 \text { E., sec. } 5 \\
\text { T. } 4 \text { S., R. } 12 \text { W., sec. } 26 \\
\text { T. } 4 \text { S., R. } 11 \text { W., sec. } 30 \\
\text { T. } 5 \text { S., R. } 12 \text { W., sec. } 13 \\
\text { T. } 11 \text { S., R. } 4 \text { E., sec. } 24 \\
\text { T. } 11 \text { S., R. } 4 \text { E., sec. } 9\end{array}$ & $\begin{array}{l}\text { Wasatch } \\
\text { Wasatch } \\
\text { Wasatch } \\
\text { Wasatch } \\
\text { Utah } \\
\text { Utah }\end{array}$ & $\begin{array}{l}\text { Baars, 1972; Baker, 1976; Biek, 1991; Bissell, 1962; Bryant and Nichols, 1988; Bryant and } \\
\text { others, 1989a, 1989b; Fouch, 1976; Fouch and others, 1982, 1983; Franczyk and others, 1992; } \\
\text { Greenhalgh, 1980; Gutschick and others, 1980; Hintze, 1988; Imlay, 1967, 1980; Lawton, 1982, } \\
\text { 1985; Lochman-Balk, 1972, 1976; McGookey and others, 1972; Nichols and Bryant, 1986a, } \\
\text { 1986b; Pipiringos and O' Sullivan, 1978; Poole and Sandberg, 1977; Poole and Stewart, 1964; } \\
\text { Poole and Claypool, 1984; Rigby and Clark, 1962; Ryder and others, 1976; Sandberg and } \\
\text { Gutschick, 1979, 1984; Sandberg and others, 1982; Spreng, 1979; Sprinkel and Waanders, 1984; } \\
\text { Stokes, 1986; Witkind and Page, 1983 }\end{array}$ \\
\hline $\begin{array}{l}\text { Zone of imbricate } \\
\text { thrusts and diapirism }\end{array}$ & $\begin{array}{l}15 \\
16 \\
17 \\
18 \\
19 \\
20 \\
21 \\
22 \\
23 \\
24 \\
25\end{array}$ & $\begin{array}{l}\text { Phillips } \\
\text { Placid } \\
\text { Placid } \\
\text { Placid } \\
\text { Placid } \\
\text { Amoco } \\
\text { Dixel } \\
\text { Mobil } \\
\text { Phillips } \\
\text { Tennessee Gas } \\
\text { Hanson Oil }\end{array}$ & $\begin{array}{l}\text { Neilson-Seagar 1 } \\
\text { WXC-Howard 1A } \\
\text { WXC-Howard 2 } \\
\text { WXC-State 1 } \\
\text { WXC-Barton 1 } \\
\text { Sevier Bridge Unit 1 } \\
\text { Gunnison State 1 } \\
\text { Larson Unit 1 } \\
\text { Price N-1 } \\
\text { Irons 1 } \\
\text { Moroni 1AX }\end{array}$ & $\begin{array}{l}\text { T. } 13 \text { S., R. } 2 \text { E., sec. } 1 \\
\text { T. } 14 \text { S., R. } 1 \text { W., sec. } 5 \\
\text { T. } 14 \text { S., R. } 1 \text { W., sec. } 5 \\
\text { T. } 15 \text { S., R. } 11 / 2 \text { W., sec. } 36 \\
\text { T. } 16 \text { S., R. } 1 \text { W., sec. } 32 \\
\text { T. } 16 \text { S., R. } 1 \text { W., sec. } 11 \\
\text { T. } 16 \text { S., R. } 1 \text { E., sec. } 15 \\
\text { T. } 17 \text { S., R. } 2 \text { E., sec. } 1 \\
\text { T. } 15 \text { S., R. } 3 \text { E., sec. } 29 \\
\text { T. } 15 \text { S., R. } 3 \text { E., sec. } 16 \\
\text { T. } 15 \text { S., R. } 3 \text { E., sec. } 14\end{array}$ & $\begin{array}{l}\text { Sanpete } \\
\text { Juab } \\
\text { Juab } \\
\text { Juab } \\
\text { Juab } \\
\text { Juab } \\
\text { Juab } \\
\text { Sanpete } \\
\text { Sanpete } \\
\text { Sanpete } \\
\text { Sanpete }\end{array}$ & $\begin{array}{l}\text { Auby, 1991; Baars, 1972; Banks, 1991, Biek, 1991; Blakey, 1974; Bryant and others, 1989a, } \\
\text { 1989b; Fouch and others, 1982, 1983; Franczyk and others, 1992; Gilliland, 1963; Gutschick and } \\
\text { others, 1980; Hardy, 1952; Hintze, 1988; Imlay, 1967, 1980; Irwin, 1971, Jefferson, 1982; } \\
\text { Kowallis and Heaton, 1987; Lawton, 1982, 1983, 1985, 1986; Lochman-Balk, 1972, 1976; } \\
\text { Mattox, 1987, 1989; Marcantel and Weiss, 1968; McGookey and others, 1972; Oviatt, 1992; } \\
\text { Pipiringos and O'Sullivan, 1978; Poole and Sandberg, 1977; Rawson and Turner-Peterson, 1979; } \\
\text { Rigby and Clark, 1962; Sandberg and Gutschick, 1979, 1984; Sandberg and others, 1982; } \\
\text { Spieker, 1946, 1949; Sprinkel, 1982; Sprinkel and Waanders, 1984; Standlee, 1982; Stanley and } \\
\text { Collinson, 1979; Stokes, 1972, 1986; Tschudy and others, 1984; Villien and Kligfield, 1986; } \\
\text { Weiss, 1982, 1990; Weiss and Roche, 1988; Welsh and Bissell, 1979; Welsh and others, 1979; } \\
\text { Willis, 1986, 1988, 1991; Witkind, 1982; Witkind and Hardy, 1983; Witkind and Page, 1983, } \\
\text { 1984; Witkind and others, 1986, 1987; Witkind and Marvin, 1989 }\end{array}$ \\
\hline $\begin{array}{l}\text { Wasatch Plateau - San } \\
\text { Rafael Swell }\end{array}$ & $\begin{array}{l}12 \\
26 \\
27 \\
28 \\
29 \\
30 \\
31 \\
\end{array}$ & $\begin{array}{l}\text { Energy Reserves } \\
\text { Phillips } \\
\\
\text { BWAB } \\
\text { Pan American } \\
\text { Husky Oil } \\
\text { Hammon } \\
\end{array}$ & $\begin{array}{l}\text { Indianola Unit Well } 1 \\
\text { USA E-1 } \\
\text { Surface control } \\
\text { Orangeville Unit } 1 \\
\text { Ferron Unit 1 } \\
\text { Castledale-Dennison } 1 \\
\text { USA Federal 8-1 } \\
\end{array}$ & $\begin{array}{l}\text { T. } 11 \text { S., R. } 5 \text { E., sec. } 27 \\
\text { T. } 19 \text { S., R. } 3 \text { E., sec. } 27 \\
\text { T. } 19 \text { S., R. } 7 \text { E., sec. } 1 \\
\text { T. } 20 \text { S., R. } 7 \text { E., sec. } 21 \\
\text { T. } 19 \text { S., R. } 8 \text { E., sec. } 10 \\
\text { T. } 19 \text { S., R. } 9 \text { E., sec. } 8 \\
\end{array}$ & $\begin{array}{l}\text { Utah } \\
\text { Sanpete } \\
\text { Emery } \\
\text { Emery } \\
\text { Emery } \\
\text { Emery } \\
\text { Emery } \\
\end{array}$ & $\begin{array}{l}\text { Baars, 1972; Blakey, 1974; Fouch and others, 1982, 1983; Franczyk and others, 1992; Gilluly, } \\
\text { 1929; Hintze, 1988; Imlay, 1967, 1980; Irwin, 1971; Kowallis and Heaton, 1987; Lawton, 1983, } \\
\text { 1986; Lochman-Balk, 1972, 1976; Loope and others, 1990; McGookey and others, 1972; } \\
\text { Pipiringos and O'Sullivan, 1978; Rawson and Turner-Peterson, 1979; Ryer and Mchillips, 1983; } \\
\text { Sanderson and Verville, 1990; Spieker, 1946, 1949; Stokes, 1944, 1986; Tschudy and others, } \\
\text { 1984; Welsh and Bissell, 1979; Welsh and others, 1979; Witkind, 1988; Witkind and others, } 1987\end{array}$ \\
\hline
\end{tabular}


Table 2. Stratigraphic thicknesses of units in the Absaroka thrust plate

\begin{tabular}{|c|c|c|c|c|c|c|c|}
\hline \multirow{3}{*}{ Age* } & \multirow{3}{*}{ Formation } & \multicolumn{6}{|c|}{ Data point } \\
\hline & & 1 & 2 & 3 & 4 & 5 & 6 \\
\hline & & \multicolumn{6}{|c|}{ Thickness (ft) } \\
\hline $\mathbf{T}$ & Wasatch Formation & $\ldots$ & 300 & 1790 & 1673 & 3450 & $-\cdots$ \\
\hline TK & Evanston Formation & --.- & --- & 1352 & 1644 & 1660 & $\ldots$ \\
\hline $\mathbf{K}$ & Echo Canyon Conglomerate & -- & -.-- & -.- & --- & $\cdots$ & --- \\
\hline $\mathbf{K}$ & Henefer Formation & $\ldots$ & $\ldots$ & ---- & --- & $\ldots$ & --- \\
\hline $\mathrm{K}$ & Frontier Formation & 1191 & 1460 & 1724 & 718 & 980 & 2000 \\
\hline $\mathrm{K}$ & Aspen Shale & 320 & 320 & 368 & 325 & 210 & 300 \\
\hline $\mathrm{K}$ & Kelvin Formation & 3329 & 3452 & 3622 & 3945 & 3440 & 6050 \\
\hline $\mathbf{J}$ & Stump Sandstone & 525 & 404 & 370 & 418 & 360 & 256 \\
\hline $\mathbf{J}$ & Preuss Sandstone & 1283 & 124 & 1382 & 1690 & 2035 & 1696 \\
\hline J & Twin Creek Limestone & 1800 & 1453 & 1426 & 1405 & 1733 & 1813 \\
\hline $\mathbf{J}$ & Gypsum Spring Member of Twin Creek Limestone & 117 & 89 & 66 & 69 & 47 & 63 \\
\hline $\mathbf{J}$ & Nugget Sandstone & 1209 & 1106 & 88 & 1473 & 1268 & 96 \\
\hline TR & Upper Member of Ankareh Formation & 267 & 250 & $\ldots$ & 180 & --- & $-\ldots$ \\
\hline $\mathrm{TR}$ & Gartra(?) Member of Ankareh Formation & 50 & 52 & --- & 60 & --- & $-\ldots$ \\
\hline $\mathrm{TR}$ & Mahogany Member of Ankareh Formation & 834 & 925 & ..-- & 720 & -.-- & ---- \\
\hline TR & Thaynes Formation & 1519 & 1520 & -.-- & 1324 & --.- & -..- \\
\hline TR & Woodside Shale & 851 & 453 & -.-- & 338 & $\ldots$ & --.- \\
\hline TR & Dinwoody Formation & 245 & 442 & -.-- & -..- & -..- & $-\ldots$ \\
\hline $\mathbf{P}$ & Phosphoria Formation & 908 & 1570 & -..- & --- & -..- & -..- \\
\hline PP & Weber Sandstone & 832 & 50 & --- & --- & --- & $\ldots$ \\
\hline $\mathbf{P}$ & Morgan Formation & 145 & -... & ---. & -..- & -.-- & -.-- \\
\hline $\mathbf{P}$ & Round Valley Limestone & 439 & --- & -- & --- & --- & --- \\
\hline $\mathbf{M}$ & Brazer Dolomite & 974 & ...- & -.-- & -.- & -.- & $-\cdots$ \\
\hline $\mathbf{M}$ & Lodgepole Limestone & 977 & -.- & -.-- & - & ---- & $\ldots$ \\
\hline D & Three Forks Formation & 271 & --.- & --.- & --- & --- & ---- \\
\hline D & Jefferson Formation & 264 & --- & $\ldots$ & --- & $\ldots$ & --- \\
\hline 0 & Bighorn Dolomite & 180 & $\ldots$ & ---- & -..- & --- & $\ldots$ \\
\hline
\end{tabular}

* T, Tertiary; TK, Tertiary and Cretaceous; K, Cretaceous; J, Jurassic; TR, Triassic; P, Permian; PP, Permian and Pennsylvanian; P, Pennsylvanian; M, Mississippian; D, Devonian; O, Ordovician. 
Table 3. Stratigraphic thicknesses of units near the western projection of the Uinta Mountains and in the Charleston-Nebo thrust plate

\begin{tabular}{|c|c|c|c|c|c|c|}
\hline \multirow[b]{3}{*}{ Age $^{*}$} & \multirow[b]{3}{*}{ Formation } & \multicolumn{5}{|c|}{ Data point } \\
\hline & & 7 & 8 & 9 & 10 & 11 \\
\hline & & \multicolumn{5}{|c|}{ Thickness (ft) } \\
\hline $\mathrm{T}$ & Keetley Volcanics & 1500 & +--- & $\cdots$ & $-\cdots$ & --- \\
\hline $\mathrm{T}$ & Duchesne River Formation & --- & --- & --- & 980 & ---- \\
\hline $\mathrm{T}$ & Green River Formation & ---- & --- & 4360 & 4120 & 5496 \\
\hline $\mathrm{T}$ & North Horn Formation & --- & --- & 1960 & 2220 & 2864 \\
\hline K & Frontier Formation & 1500 & ---- & --- & ---- & ---- \\
\hline $\mathbf{K}$ & Aspen Shale & 500 & --- & --- & ---- & $-\cdots$ \\
\hline $\mathbf{K}$ & Kelvin Formation & 3000 & --- & --- & ---- & ---- \\
\hline $\mathrm{KJ}$ & Morrison Formation & 300 & --- & --- & ---- & ---- \\
\hline $\mathbf{J}$ & Stump Sandstone & 150 & --- & ---- & --- & ---- \\
\hline $\mathbf{J}$ & Preuss Sandstone & 1100 & --- & --- & ---- & --- \\
\hline $\mathbf{J}$ & Arapien(?) Shale & --- & 473 & $-\cdots$ & --- & --- \\
\hline $\mathbf{J}$ & Twin Creek Limestone & 1357 & 671 & --- & ---- & ---- \\
\hline $\mathbf{J}$ & Gypsum Springs Mbr., Twin Creek Limestone & 22 & --- & ---- & ---- & ---- \\
\hline $\mathbf{J}$ & Nugget Sandstone & 1450 & 1306 & --- & --- & ---- \\
\hline $\mathrm{TR}$ & Upper Member of Ankareh Formation & 550 & 380 & ---- & ---- & ---- \\
\hline TR & Gartra(?) Member of Ankareh Formation & 250 & 100 & ---- & ---- & ---- \\
\hline TR & Mahogany Member of Ankareh Formation & 1050 & 968 & --- & ---- & --- \\
\hline TR & Thaynes Formation & 1530 & 1196 & ..--- & --- & 739 \\
\hline TR & Woodside Shale & 450 & 462 & $-\cdots--$ & ---- & 1032 \\
\hline $\mathbf{P}$ & Park City Formation & 650 & 624 & --- & --- & 1173 \\
\hline PP & Weber Sandstone & 1500 & 222 & --- & --- & 196 \\
\hline PP & Oquirrh Formation & $-\cdots$ & 10608 & 6018 & 9500 & ---- \\
\hline $\mathbb{P}$ & Round Valley Limestone & 400 & --- & --- & ---- & ---- \\
\hline $\mathbf{P M}$ & Manning Canyon Shale & --- & 312 & --- & --- & --- \\
\hline $\mathbf{M}$ & Doughnut Formation & ---- & --- & --- & --- & --- \\
\hline $\mathbf{M}$ & Humbug Formation & --- & --- & --- & --- & --- \\
\hline M & Brazer Dolomite & 900 & ---- & --- & --- & --- \\
\hline $\mathbf{M}$ & Deseret Limestone & 500 & --- & --- & --- & --- \\
\hline $\mathbf{M}$ & Gardison Limestone & 350 & --- & --- & ---- & ---- \\
\hline MD & Fitchville Formation & 400 & --- & ---- & ---- & ---- \\
\hline$--\mathrm{C}$ & Maxfield Limestone & --- & --- & $-\cdots$ & ---- & --- \\
\hline$--\mathrm{C}$ & Ophir Shale & 350 & ---- & ---- & --- & ---- \\
\hline$--\mathrm{C}$ & Tintic Quartzite & 850 & --- & --- & $-\cdots$ & --- \\
\hline
\end{tabular}

* Symbols same as on table 2; additional symbols are KJ, Cretaceous and Jurassic; PM, Pennsylvanian and Mississippian; MD, Mississippian and Devonian; and --C, Cambrian. 
Table 4. Stratigraphic thicknesses of units in the zone of imbricate thrusts and diapirism

\begin{tabular}{|c|c|c|c|c|c|c|c|c|c|c|c|c|c|c|}
\hline \multirow[b]{3}{*}{ Age } & \multirow[b]{3}{*}{ Formation } & \multicolumn{13}{|c|}{ Data point } \\
\hline & & 13 & 14 & 15 & 16 & 17 & 18 & 19 & 20 & 21 & 22 & 23 & 24 & 25 \\
\hline & & \multicolumn{13}{|c|}{ Thickness (ft) } \\
\hline $\mathrm{T}$ & Goldens Ranch Formation & -- & 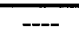 & -- & --- & - & $\ldots$ & 1641 & $\ldots$ & $\ldots$ & $\ldots$ & $\ldots$ & 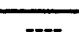 & $\ldots$ \\
\hline $\mathrm{T}$ & Crazy Hollow Formation & ---- & --- & --- & $\ldots$ & ...- & -.-- & -.-- & $\ldots$ & --- & --- & ...- & -.-- & 300 \\
\hline $\mathbf{T}$ & Green River Formation & --- & -- & --- & $\ldots$ & --- & 796 & 1076 & 1280 & $\ldots$ & $\ldots$ & 1123 & 1625 & 1355 \\
\hline $\mathbf{T}$ & Colton Formation & $-\ldots$ & -.- & $\ldots$ & $\ldots$ & ...- & 414 & --- & -..- & $\ldots$ & ---- & 392 & 415 & 425 \\
\hline $\mathrm{T}$ & Flagstaff Limestone & --- & $-\ldots$ & 475 & -..- & $\cdots$ & 295 & $\ldots$ & $\ldots$ & 1020 & 270 & 200 & 225 & 220 \\
\hline TK & North Horn Formation & ---- & 708 & 820 & 3810 & 4078 & 1840 & -..- & ...- & 2204 & 810 & 1330 & 2815 & 2780 \\
\hline $\mathbf{K}$ & Indianola Group (undivided) & 2245 & 1064 & $\ldots$ & $\ldots$ & $\ldots$ & 581 & 1733 & -..- & 3487 & $\ldots$ & -.-- & ---- & $\ldots$ \\
\hline $\mathbf{K}$ & Sixmile Canyon Formation & --- & -.-- & 8207 & $\ldots$ & $\cdots$ & $\ldots$ & --- & -..- & --- & --- & --- & 1005 & 3990 \\
\hline $\mathbf{K}$ & Funk Valley Formation & --- & $-\ldots$ & $\ldots$ & $\ldots$ & $\ldots$ & $\ldots$ & $\ldots$ & $-\ldots$ & --- & 912 & 925 & 2655 & 2480 \\
\hline $\mathbf{K}$ & Allen Valley Shale & $\cdots$ & --- & $\cdots$ & $\cdots$ & --- & --- & $\cdots$ & $\cdots$ & $\ldots$ & 202 & 397 & 535 & 520 \\
\hline $\mathbf{K}$ & Sanpete Formation & $\cdots$ & --- & --- & --- & $\cdots$ & --- & --- & $\cdots$ & $\cdots$ & 466 & 821 & 255 & 302 \\
\hline $\mathbf{K}$ & unnamed conglomerate & --- & --- & $\cdots$ & 1078 & 1099 & 922 & 767 & --- & 2033 & 985 & 702 & --- & 733 \\
\hline $\mathbf{K}$ & Cedar Mountain Formation & $\cdots$ & --- & $\cdots$ & --- & --- & --- & 205 & $\cdots$ & 862 & 1686 & 670 & $\ldots-$ & 595 \\
\hline $\mathbf{J}$ & Twist Gulch Formation & --- & -- & ---- & $-\cdots$ & --- & --- & 308 & --- & 1162 & 1595 & 1545 & $\cdots$ & 873 \\
\hline $\mathbf{J}$ & Arapien Shale & 5159 & 3114 & --- & 4342 & 4117 & 2733 & 1820 & 3489 & 3668 & 6437 & 3762 & -..- & 2737 \\
\hline $\mathbf{J}$ & Twin Creek Limestone & $\cdots$ & 584 & --- & 1140 & 1056 & 959 & 560 & 421 & 309 & --- & ---- & -- & 540 \\
\hline $\mathbf{J}$ & Gypsum Springs Member of Twin Creek Limestone & $-\cdots$ & $\cdots$ & $-\ldots$ & 274 & 212 & 344 & 162 & 45 & $\ldots$ & $\ldots$ & $\ldots$ & $\cdots$ & --- \\
\hline $\mathbf{J}$ & Navajo Sandstone & --- & 1155 & --- & 1450 & 202 & 975 & 1246 & 1241 & 1088 & --- & --- & --- & 685 \\
\hline $\mathrm{TR}$ & Petrified Forest Member of Chinle Formation & $\ldots$ & $\cdots$ & $\cdots$ & 56 & $\cdots$ & $\cdots$ & 367 & 538 & --- & --- & --- & --- & 25 \\
\hline TR & Moss Back Member of Chinle Formation & -- & --- & --- & --- & --- & --- & 162 & 113 & - & ---- & - & -- & 70 \\
\hline$T_{R}$ & Moenkopi Formation & $\cdots$ & --- & --- & -- & -- & -- & 1990 & 1593 & --- & --- & - & $\ldots$ & 1870 \\
\hline $\mathbf{P}$ & Black Box Dolomite & $\cdots$ & - & -- & --- & $\ldots$ & $\ldots$ & 235 & -- & $\cdots$ & $\ldots$ & - & - & 340 \\
\hline $\mathbf{P}$ & Toroweap Formation & $\cdots$ & $\cdots$ & $\ldots$ & 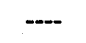 & $\cdots$ & $\cdots$ & 1083 & - & -- & $\ldots$ & $\ldots$ & -- & 424 \\
\hline $\mathbf{M}$ & Humbug Formation & - & -- & $\cdots$ & --- & -- & - & 87 & -- & - & --- & - & - & -- \\
\hline $\mathbf{M}$ & Deseret Limestone & -- & -- & -- & -- & --- & - & 920 & - & --- & --- & --- & -- & --- \\
\hline $\mathbf{M}$ & Gardison Limestone & $\ldots$ & -- & - & $\cdots$ & -- & -.- & 584 & --- & $\ldots$ & -.-- & $\ldots$ & $\ldots$ & $\ldots$ \\
\hline MD & Fitchville Formation & $\ldots$ & --- & $\ldots$ & - &.-- & --- & 246 & -- & $\ldots$ & $\ldots$ & --- & - & $\ldots$ \\
\hline D & Pinyon Peak Limestone & $\ldots$ & $\ldots$ & $\ldots$ & $\cdots$ & $\ldots$ & $\ldots$ & 187 & $\ldots$ & $\ldots$ & -- & $\ldots$ & $\ldots$ & $\ldots$ \\
\hline$-\mathrm{C}$ & Cambrian(?) rocks, undivided & $\ldots$ & -- & -- & -..- & $-\ldots$ & --. & 848 & $\ldots$ & $\ldots$ & -.- & $\ldots$ & -.- & $\ldots$ \\
\hline
\end{tabular}

* Symbols same as on tables 2 and 3. 
Table 5. Stratigraphic thicknesses of units in Wasatch Plateau and northwestern margin of the San Rafael Swell

\begin{tabular}{|c|c|c|c|c|c|c|c|c|}
\hline \multirow[b]{3}{*}{ Age* } & \multirow[b]{3}{*}{ Formation } & \multicolumn{7}{|c|}{ Data points } \\
\hline & & 12 & 26 & 27 & 28 & 29 & 30 & 31 \\
\hline & & \multicolumn{7}{|c|}{ Thickness (ft) } \\
\hline $\mathrm{T}$ & Flagstaff Limestone & 1000 & $\overline{---}$ & 1000 & $\ldots$ & --- & -- & $\overline{---}$ \\
\hline TK & North Horn Formation & 3961 & 1205 & 300 & --- & -- & -- & -- \\
\hline $\mathbf{K}$ & Price River Formation & 1189 & 951 & 1200 & -- & -..- & -- & -- \\
\hline $\mathbf{K}$ & Castlegate Sandstone & 640 & 407 & 500 & $\cdots$ & $\cdots$ & -- & --- \\
\hline $\mathbf{K}$ & Blackhawk Formation & 980 & 942 & 1000 & --- & --- & --- & -- \\
\hline $\mathbf{K}$ & Star Point Sandstone & 267 & 654 & 350 & $\ldots$ & $\cdots$ & --- & --- \\
\hline $\mathbf{K}$ & upper part Blue Gate Mbr., Mancos Shale & 221 & 396 & 1000 & --- & -- & --- & $-\ldots$ \\
\hline $\mathbf{K}$ & Emery Sandstone Mbr., Mancos Shale & 1882 & 2135 & 285 & --- & --- & -- & $\cdots$ \\
\hline $\mathbf{K}$ & lower part Blue Gate Mbr., Mancos Shale & 1050 & 1402 & 200 & 218 & 798 & 125 & --- \\
\hline $\mathbf{K}$ & Ferron Sandstone Mbr., Mancos Shale & 660 & 712 & 340 & 306 & 312 & 288 & --- \\
\hline $\mathbf{K}$ & Tununk Mbr., Mancos Shale & 326 & 579 & 550 & 586 & 568 & 513 & -- \\
\hline $\mathbf{K}$ & Dakota Sandstone & 559 & 670 & 30 & 20 & 62 & 149 & -- \\
\hline $\mathbf{K}$ & unnamed conglomerate & 269 & 219 & - & - & $\ldots$ & - & -- \\
\hline $\mathbf{K}$ & Cedar Mountain Formation & 654 & 690 & 500 & 493 & 445 & 13 & 755 \\
\hline KJ & Morrison Formation & ---- & --- & 350 & 418 & 304 & --- & 445 \\
\hline J & Summerville Formation & 774 & 555 & - & 350 & 406 & $-\cdots$ & 260 \\
\hline $\mathbf{J}$ & Curtis Formation & 194 & 172 & --- & 173 & 90 & --- & 160 \\
\hline J & Entrada Sandstone & - & $\cdots$ & - & 680 & 800 & $-\cdots$ & 650 \\
\hline $\mathbf{J}$ & Twist Gulch Formation & 1212 & 504 & --- & --- & -- & -- & -- \\
\hline $\mathbf{J}$ & upper part of Carmel Formation & $\ldots$ & - & - & 590 & 497 & --- & 168 \\
\hline $\mathbf{J}$ & lower part of Carmel Formation & $\ldots$ & --- & --- & 259 & 523 & --- & 462 \\
\hline $\mathbf{J}$ & Arapien Shale & 588 & 968 & $-\ldots$ & --- & --- & --- & --- \\
\hline $\mathbf{J}$ & Twin Creek Limestone & 527 & 570 & $\ldots$ & --- & --- & --- & -- \\
\hline $\mathbf{J}$ & Navajo Sandstone & 96 & 619 & --- & 487 & 610 & --- & 433 \\
\hline $\mathbf{J}$ & Kayenta Formation & $\ldots$ & 270 & --- & 162 & 210 & --- & 247 \\
\hline $\mathbf{J}$ & Wingate Sandstone & --- & 330 & ---- & 344 & 267 & --- & 270 \\
\hline TR & Petrified Forest Mbr., Chinle Formation & --- & 300 & $-\cdots$ & 98 & 138 & --- & 105 \\
\hline $\mathrm{TR}$ & Moss Back Mbr., Chinle Formation & $\ldots$ & 78 & $\ldots$ & 80 & 123 & $\cdots$ & 188 \\
\hline TR & Moenkopi Formation & --- & 1467 & --- & 1120 & 997 & --- & 897 \\
\hline $\mathbf{P}$ & Black Box Dolomite & - & 183 & -- & 134 & 150 & --- & 75 \\
\hline $\mathbf{P}$ & White Rim Sandstone & - & 479 & -- & 76 & 443 & --- & 480 \\
\hline $\mathbf{M}$ & Redwall Limestone & --- & 755 & $-\cdots$ & $-\cdots$ & 369 & --- & 305 \\
\hline D & Ouray Limestone & --- & 116 & --- & - & 143 & --- & 67 \\
\hline D & Elbert Formation & $-\cdots$ & 449 & $-\cdots$ & --- & 385 & $\cdots$ & 248 \\
\hline$--\mathrm{C}$ & Lynch Dolomite & --- & 639 & --- & --- & 512 & --- & $\ldots$ \\
\hline$-\mathrm{C}$ & Maxfield Limestone & --- & 677 & --- & --- & 568 & -- & --. \\
\hline$-\mathrm{C}$ & Ophir Formation & --- & 231 & --- & --- & 211 & -- & -.. \\
\hline$-\mathrm{C}$ & Tintic Quartzite & - & 126 & --- & $\ldots$ & 91 & --- & --- \\
\hline
\end{tabular}

* Symbols same as on tables 2 and 3. 


\begin{abstract}
APPENDIX
The appendix contains the well information used to construct the cross sections. It gives the data-point number used to locate the well on the cross sections and in figure 4, the operator's name (OPERATOR), the well name (WELL NAME), the well location (by section, township, and range) (LOCATION), the county in which the well is located (COUNTY), the elevation of the Kelly Bushing (KB), and the total depth of penetration (TD). The appendix also lists names of formations identified in the well (FORMATION), the depth at which the formation was picked from well logs (TOPS), formation thickness

(THICK), and elevation of the formation relative to sea level (SUBSEA). All depths (negative numbers), elevations, and thicknesses are reported in feet.

The first formation listed for each well is the surface formation mapped at that location. It is indicated with a "TOP" of zero. Formations noted with the word "ESTIMATED" by the formation name or that may have a "TOP" of zero, indicate that I was uncertain about the exact location of the subsurface contact or that the well logs available to me were not run over that interval.
\end{abstract}


APPENDIX

\begin{tabular}{|c|c|c|c|c|c|c|c|c|c|c|}
\hline $\begin{array}{l}\text { Data } \\
\text { point }\end{array}$ & Operator & Well name & Location & County & $\begin{array}{l}\mathrm{KB} \\
\text { (ft) }\end{array}$ & $\begin{array}{l}\text { TD } \\
\text { (ft) }\end{array}$ & Formation & $\begin{array}{l}\text { Top } \\
\text { (ft) }\end{array}$ & $\begin{array}{r}\text { Thickness } \\
\text { (ft) }\end{array}$ & $\begin{array}{r}\text { Subsea } \\
(\mathrm{ft})\end{array}$ \\
\hline \multirow[t]{26}{*}{1} & \multirow[t]{26}{*}{ Amoco } & \multirow[t]{26}{*}{ Island Ranching D-1 } & \multirow{26}{*}{$\begin{array}{l}\text { NW1/4NW1/4 Sec. 14, } \\
\text { T. } 4 \text { N., R. } 7 \text { E. }\end{array}$} & \multirow[t]{26}{*}{ Summit } & \multirow{26}{*}{7401} & \multirow[t]{26}{*}{18810} & Frontier Formation & 0 & 1191 & 7401 \\
\hline & & & & & & & Aspen Shale & 1191 & 320 & 6210 \\
\hline & & & & & & & Kelvin Formation & 1511 & 3329 & 5890 \\
\hline & & & & & & & Stump Sandstone & 4840 & 525 & 2561 \\
\hline & & & & & & & Preuss Sandstone & 5365 & 1283 & 2036 \\
\hline & & & & & & & Twin Creek Limestone & 6648 & 1800 & 753 \\
\hline & & & & & & & Gypsum Spring Member of Twin Creek Limestone & 8448 & 117 & -1047 \\
\hline & & & & & & & Nugget Sandstone & 8565 & 1209 & -1164 \\
\hline & & & & & & & Upper Member of Ankareh Formation & 9774 & 267 & -2373 \\
\hline & & & & & & & Gartra Member of Ankareh Formation & 10041 & 50 & -2640 \\
\hline & & & & & & & Mahogany Member Ankareh Formation & 10091 & 834 & -2690 \\
\hline & & & & & & & Thaynes Formation & 10925 & 1519 & -3524 \\
\hline & & & & & & & Woodside Shale & 12444 & 851 & -5043 \\
\hline & & & & & & & Dinwoody(?) Formation & 13295 & 245 & -5894 \\
\hline & & & & & & & Phosphoria Formation & 13540 & 908 & -6139 \\
\hline & & & & & & & Weber Sandstone & 14448 & 832 & -7047 \\
\hline & & & & & & & Morgan Formation & 15280 & 145 & -7879 \\
\hline & & & & & & & Round Valley Limestone & 15425 & 439 & -8024 \\
\hline & & & & & & & Brazer Dolomite & 15864 & 974 & -8463 \\
\hline & & & & & & & Lodgepole Limestone & 16838 & 977 & -9437 \\
\hline & & & & & & & Three Forks Formation & 17815 & 271 & -10414 \\
\hline & & & & & & & Jefferson Formation & 18086 & 264 & -10685 \\
\hline & & & & & & & Bighorn Dolomite & 18350 & 180 & -10949 \\
\hline & & & & & & & Thrust & 18530 & 0 & -11129 \\
\hline & & & & & & & Aspen(?) Shale & 18530 & 280 & -11129 \\
\hline & & & & & & & TD & 18810 & & -11409 \\
\hline \multirow[t]{16}{*}{2} & \multirow[t]{16}{*}{ Anschutz } & \multirow[t]{16}{*}{ Anschutz Ranch 3-1 } & \multirow{16}{*}{$\begin{array}{l}\text { NW1/4NW1/4 sec. } 3 \text {, } \\
\text { T. } 3 \text { N., R. } 7 \text { E. }\end{array}$} & \multirow[t]{16}{*}{ Summit } & \multirow[t]{16}{*}{7222} & \multirow[t]{16}{*}{13970} & Wasatch Formation & 0 & 300 & 7222 \\
\hline & & & & & & & Frontier Formation (estimated top) & 300 & 1460 & 6922 \\
\hline & & & & & & & Aspen Shale & 1760 & 320 & 5462 \\
\hline & & & & & & & Kelvin Formation & 2080 & 3452 & 5142 \\
\hline & & & & & & & Stump Sandstone & 5532 & 404 & 1690 \\
\hline & & & & & & & Preuss Sandstone & 5936 & 124 & 1286 \\
\hline & & & & & & & Twin Creek Limestone & 6060 & 1453 & 1162 \\
\hline & & & & & & & Gypsum Spring Member of Twin Creek Limestone & 7513 & 89 & -291 \\
\hline & & & & & & & Nugget Sandstone & 7602 & 1106 & -380 \\
\hline & & & & & & & Upper Member of Ankareh Formation & 8708 & 250 & -1486 \\
\hline & & & & & & & Gartra Member of Ankareh Formation (estimated top) & 8958 & 52 & -1736 \\
\hline & & & & & & & Mahogany Member Ankareh Formation (estimated top) & 9010 & 925 & -1788 \\
\hline & & & & & & & Thaynes Formation & 9935 & 1520 & -2713 \\
\hline & & & & & & & Woodside Shale & 11455 & 453 & -4233 \\
\hline & & & & & & & Dinwoody(?) Formation & 11908 & 442 & -4686 \\
\hline & & & & & & & Phosphoria Formation & 12350 & 1570 & -5128 \\
\hline
\end{tabular}




\begin{tabular}{|c|c|c|c|c|c|c|c|c|c|c|}
\hline $\begin{array}{l}\text { Data } \\
\text { point }\end{array}$ & Operator & Well name & Location & County & $\begin{array}{l}\mathrm{KB} \\
\text { (ft) }\end{array}$ & $\begin{array}{l}\text { TD } \\
\text { (ft) }\end{array}$ & Formation & $\begin{array}{l}\text { Top } \\
\text { (ft) }\end{array}$ & $\begin{array}{r}\text { Thickness } \\
\text { (ft) } \\
\end{array}$ & $\begin{array}{r}\text { Subsea } \\
\text { (ft) } \\
\end{array}$ \\
\hline \multirow{13}{*}{3} & \multirow{13}{*}{ American Quasar } & \multirow{13}{*}{ UPRR 27-1 } & \multirow{13}{*}{$\begin{array}{l}\text { SE } 1 / 4 \mathrm{SE}^{1 / 4} \mathrm{sec} .27 \text {, } \\
\text { T. } 2 \text { N., R. } 6 \text { E. }\end{array}$} & \multirow{13}{*}{ Summit } & \multirow{13}{*}{7878} & \multirow{13}{*}{12188} & Weber Sandstone & 13920 & 50 & -6698 \\
\hline & & & & & & & TD & 13970 & & -6748 \\
\hline & & & & & & & Wasatch Formation & 0 & 1790 & 7878 \\
\hline & & & & & & & Evanston Formation (estimated top) & 1790 & 1352 & 6088 \\
\hline & & & & & & & Frontier Formation & 3142 & 1724 & 4736 \\
\hline & & & & & & & Aspen Shale & 4866 & 368 & 3012 \\
\hline & & & & & & & Kelvin Formation & 5234 & 3622 & 2644 \\
\hline & & & & & & & Stump Sandstone & 8856 & 370 & -978 \\
\hline & & & & & & & Preuss Sandstone & 9226 & 1382 & -1348 \\
\hline & & & & & & & Twin Creek Limestone & 10608 & 1426 & -2730 \\
\hline & & & & & & & Gypsum Spring Member of Twin Creek Limestone & 12034 & 66 & -4156 \\
\hline & & & & & & & Nugget Sandstone & 12100 & 88 & -4222 \\
\hline & & & & & & & TD & 12188 & & -4310 \\
\hline \multirow[t]{19}{*}{4} & \multirow[t]{19}{*}{ American Quasar } & \multirow[t]{19}{*}{ UPRR 35-1 } & \multirow{19}{*}{$\begin{array}{l}\text { SE } 1 / 4 N^{1} 1 / 4 \text { sec. } 35 \text {, } \\
\text { T. } 2 \text { N., R. } 6 \text { E. }\end{array}$} & \multirow[t]{19}{*}{ Summit } & \multirow[t]{19}{*}{7300} & \multirow[t]{19}{*}{17053} & Wasatch Formation & 0 & 1673 & 7300 \\
\hline & & & & & & & Evanston Formation & 1673 & 1644 & 5627 \\
\hline & & & & & & & Frontier Formation & 3317 & 718 & 3983 \\
\hline & & & & & & & Aspen Shale & 4035 & 325 & 3265 \\
\hline & & & & & & & Kelvin Formation & 4360 & 3945 & 2940 \\
\hline & & & & & & & Stump Sandstone & 8305 & 418 & -1005 \\
\hline & & & & & & & Preuss Sandstone & 8723 & 1690 & -1423 \\
\hline & & & & & & & Twin Creek Limestone & 10413 & 1405 & -3113 \\
\hline & & & & & & & Gypsum Spring Member of Twin Creek Limestone & 11818 & 69 & -4518 \\
\hline & & & & & & & Nugget Sandstone & 11887 & 1473 & -4587 \\
\hline & & & & & & & Upper Member of Ankareh Formation & 13360 & 180 & -6060 \\
\hline & & & & & & & Gartra Member of Ankareh Formation & 13540 & 60 & -6240 \\
\hline & & & & & & & Mahogany Member Ankareh Formation & 13600 & 720 & -6300 \\
\hline & & & & & & & Thaynes Formation & 14320 & 1324 & -7020 \\
\hline & & & & & & & Woodside Shale & 15644 & 338 & -8344 \\
\hline & & & & & & & Thrust & 15982 & 0 & -8682 \\
\hline & & & & & & & Aspen Shale & 15982 & 358 & -8682 \\
\hline & & & & & & & Kelvin Formation & 16340 & 713 & -9040 \\
\hline & & & & & & & TD & 17053 & & -9753 \\
\hline \multirow[t]{11}{*}{5} & \multirow[t]{11}{*}{ Exxon } & \multirow[t]{11}{*}{ UPRR 9-1 } & \multirow{11}{*}{$\begin{array}{l}\text { NE1/4SW1/4 sec. 9, } \\
\text { T. } 1 \text { N., R. } 6 \text { E. }\end{array}$} & \multirow[t]{11}{*}{ Summit } & \multirow[t]{9}{*}{8201} & \multirow[t]{7}{*}{15183} & Wasatch Formation & 0 & 3450 & 8201 \\
\hline & & & & & & & Evanston Formation (estimated top) & 3450 & 1660 & 4751 \\
\hline & & & & & & & Frontier Formation & 5110 & 980 & 3091 \\
\hline & & & & & & & Aspen Shale & 6090 & 210 & 2111 \\
\hline & & & & & & & Kelvin Formation & 6300 & 3440 & 1901 \\
\hline & & & & & & & Stump Sandstone & 9740 & 360 & -1539 \\
\hline & & & & & & & Preuss Sandstone & 10100 & 2035 & -1899 \\
\hline & & & & & & & Twin Creek Limestone & 12135 & 1733 & -3934 \\
\hline & & & & & & & Gypsum Spring Member of Twin Creek Limestone & 13868 & 47 & -5667 \\
\hline & & & & & & & Nugget Sandstone & 13915 & 1268 & -5714 \\
\hline & & & & & & & $\mathrm{TD}$ & 15183 & & -6982 \\
\hline 6 & Amoco & Rockport Reservoir 1 & $\mathrm{SW}^{1} 1 / 4 \mathrm{SE}^{1 / 4} \mathrm{sec} .21$ & Summit & 6715 & 12274 & Frontier Formation & 0 & 2000 & 6715 \\
\hline & & & T. 1 N., R. 5 E. & & & & Aspen Shale & 2000 & 300 & 4715 \\
\hline
\end{tabular}




\begin{tabular}{|c|c|c|c|c|c|c|c|c|c|c|}
\hline $\begin{array}{l}\text { Data } \\
\text { point }\end{array}$ & Operator & Well name & Location & County & $\begin{array}{l}\mathbf{K B} \\
(\mathrm{ft}) \\
\end{array}$ & $\begin{array}{l}\text { TD } \\
\text { (ft) }\end{array}$ & Formation & $\begin{array}{l}\text { Top } \\
\text { (ft) }\end{array}$ & $\begin{array}{r}\text { Thickness } \\
(\mathrm{ft})\end{array}$ & $\begin{array}{r}\text { Subsea } \\
(\mathrm{ft}) \\
\end{array}$ \\
\hline & & & & & & & $\begin{array}{l}\text { Kelvin Formation } \\
\text { Stump Sandstone } \\
\text { Preuss Sandstone } \\
\text { Twin Creek Limestone } \\
\text { Gypsum Spring Member of Twin Creek Limestone } \\
\text { Nugget Sandstone } \\
\text { TD }\end{array}$ & $\begin{array}{r}2300 \\
8350 \\
8606 \\
10302 \\
12115 \\
12178 \\
12274\end{array}$ & $\begin{array}{r}6050 \\
256 \\
1696 \\
1813 \\
63 \\
96\end{array}$ & $\begin{array}{r}4415 \\
-1635 \\
-1891 \\
-3587 \\
-5400 \\
-5463 \\
-5559\end{array}$ \\
\hline 7 & Surface control & USGS Map GQ-852, GQ-864 & & & & & & & & \\
\hline \multirow[t]{13}{*}{8} & Placid & Daniels Land 1 & NW1/4NW1/4 sec. 5 , & $\begin{array}{l}\text { Wasatc } \\
\text { h }\end{array}$ & 7575 & 17322 & Oquirrh Formation & 10600 & 10608 & 7575 \\
\hline & & & T. 5 S., R. 5 E. & & & & $\begin{array}{l}\text { Manning Canyon Shale } \\
\text { Thrust }\end{array}$ & $\begin{array}{l}10608 \\
10920\end{array}$ & $\begin{array}{r}312 \\
0\end{array}$ & $\begin{array}{l}-3033 \\
-3345\end{array}$ \\
\hline & & & & & & & Arapien(?) Shale & 10920 & 473 & -3345 \\
\hline & & & & & & & Twin Creek Limestone & 11393 & 671 & -3818 \\
\hline & & & & & & & Nugget Sandstone & 12064 & 1306 & -4489 \\
\hline & & & & & & & Upper Member of Ankareh Formation & 13370 & 380 & -5795 \\
\hline & & & & & & & Gartra Member of Ankareh Formation & 13750 & 100 & -6175 \\
\hline & & & & & & & Mahogany Member Ankareh Formation & 13850 & 968 & -6275 \\
\hline & & & & & & & Thaynes Formation & 14818 & 1196 & -7243 \\
\hline & & & & & & & Woodside Shale & 16014 & 462 & -8439 \\
\hline & & & & & & & Park City Formation & 16476 & 624 & -8901 \\
\hline & & & & & & & Weber Sandstone & 17100 & 222 & -9525 \\
\hline & & & & & & & TD & 17322 & & -9747 \\
\hline \multirow[t]{3}{*}{9} & Amoco & Strawberry River 1 & $\mathrm{NE}^{1 / 4 \mathrm{NE}^{1 / 4} \mathrm{sec} .26}$ & $\begin{array}{l}\text { Wasatc } \\
\mathrm{h}\end{array}$ & 8018 & 12338 & Green River Formation & 0 & 4360 & 8018 \\
\hline & & & T. 4 S., R. 12 W. & & & & $\begin{array}{l}\text { North Horn Formation } \\
\text { Oquirrh Formation }\end{array}$ & $\begin{array}{r}4360 \\
6320\end{array}$ & $\begin{array}{l}1960 \\
6018\end{array}$ & $\begin{array}{l}3658 \\
1698\end{array}$ \\
\hline & & & & & & & TD & 12338 & & -4320 \\
\hline \multirow[t]{8}{*}{10} & Exxon & Strawberry Reservoir 1 & $\mathrm{E}^{1 / 2} \mathrm{SW} 1 / 4 \mathrm{sec} .30$ & $\begin{array}{l}\text { Wasatc } \\
\mathrm{h}\end{array}$ & 7929 & 19993 & Duchesne River Formation & 0 & 980 & 7929 \\
\hline & & & T. 4 S., R. 11 W. & & & & Green River Formation & 980 & 4120 & 6949 \\
\hline & & & & & & & North Horn Formation & 5100 & 2220 & 2829 \\
\hline & & & & & & & Oquirrh Formation & 7320 & 9500 & 609 \\
\hline & & & & & & & Thrust & 16820 & 0 & -8891 \\
\hline & & & & & & & Woodside Shale (inverted section) & 16820 & 3172 & -8891 \\
\hline & & & & & & & Thaynes Formation (inverted section) & 19992 & 1 & -12063 \\
\hline & & & & & & & TD & 19993 & & -12064 \\
\hline \multirow[t]{7}{*}{11} & Exxon & Buffalo Canyon Unit 1 & NE1/4SE1/4 sec. 13, & $\begin{array}{l}\text { Wasatc } \\
\mathrm{h}\end{array}$ & 8816 & 14201 & Green River Formation & 0 & 5496 & 8816 \\
\hline & & & T. 5 S., R. 12 W. & & & & North Horn Formation & 5496 & 2864 & 3320 \\
\hline & & & & & & & Woodside Shale & 8360 & 1020 & 456 \\
\hline & & & & & & & Park City Formation & 9380 & 552 & -564 \\
\hline & & & & & & & Thrust & 9932 & 0 & -1116 \\
\hline & & & & & & & Thaynes Formation & 9932 & 739 & -1116 \\
\hline & & & & & & & Fault & 10671 & 0 & -1855 \\
\hline
\end{tabular}




\begin{tabular}{|c|c|c|c|c|c|c|c|c|c|c|}
\hline $\begin{array}{l}\text { Data } \\
\text { point }\end{array}$ & Operator & Well name & Location & County & $\begin{array}{l}\mathrm{KB} \\
(\mathrm{ft}) \\
\end{array}$ & $\begin{array}{l}\text { TD } \\
\text { (ft) }\end{array}$ & Formation & $\begin{array}{l}\text { Top } \\
\text { (ft) }\end{array}$ & $\begin{array}{r}\text { Thickness } \\
\text { (ft) } \\
\end{array}$ & $\begin{array}{r}\text { Subsea } \\
\text { (ft) }\end{array}$ \\
\hline \multirow{25}{*}{12} & \multirow{25}{*}{$\begin{array}{l}\text { Energy Reserves } \\
\text { (Sohio) }\end{array}$} & \multirow{25}{*}{ Indianola Unit Well 1} & \multirow{25}{*}{$\begin{array}{l}\text { SE } 1 / 4 S 1 / 4 \text { sec. } 27 \\
\text { T. } 11 \text { S., R. } 5 \text { E. }\end{array}$} & \multirow{25}{*}{ Utah } & \multirow{25}{*}{9175} & \multirow{25}{*}{17049} & Woodside Shale & 10671 & 1044 & -1855 \\
\hline & & & & & & & Park City Formation & 11715 & 2290 & -2899 \\
\hline & & & & & & & Kirkman Limestone & 14005 & 196 & -5189 \\
\hline & & & & & & & TD & 14201 & & -5385 \\
\hline & & & & & & & Flagstaff Member of Green River Formation & 0 & 1000 & 9175 \\
\hline & & & & & & & North Horn Formation (estimated top) & 1000 & 3961 & 8175 \\
\hline & & & & & & & Price River Formation & 4961 & 1189 & 4214 \\
\hline & & & & & & & Castlegate Sandstone & 6150 & 640 & 3025 \\
\hline & & & & & & & Blackhawk Formation & 6790 & 980 & 2385 \\
\hline & & & & & & & Star Point Sandstone & 7770 & 267 & 1405 \\
\hline & & & & & & & Upper Part Blue Gate Member of Mancos Shale & 8037 & 221 & 1138 \\
\hline & & & & & & & Emery Sandstone Member of Mancos Shale & 8258 & 1882 & 917 \\
\hline & & & & & & & Lower Part Blue Gate Member of Mancos Shale & 10140 & 1050 & -965 \\
\hline & & & & & & & Ferron Sandstone Member of Mancos Shale & 11190 & 660 & -2015 \\
\hline & & & & & & & Tununk Member of Mancos Shale & 11850 & 326 & -2675 \\
\hline & & & & & & & Dakota Sandstone & 12176 & 559 & -3001 \\
\hline & & & & & & & Unnamed conglomerate & 12735 & 269 & -3560 \\
\hline & & & & & & & Cedar Mountain Formation & 13004 & 654 & -3829 \\
\hline & & & & & & & Summerville Formation & 13658 & 774 & -4483 \\
\hline & & & & & & & Curtis Formation & 14432 & 194 & -5257 \\
\hline & & & & & & & Twist Gulch Formation & 14626 & 1212 & -5451 \\
\hline & & & & & & & Arapien Shale & 15838 & 588 & -6663 \\
\hline & & & & & & & Twin Creek Limestone & 16426 & 527 & -7251 \\
\hline & & & & & & & Navajo Sandstone & 16953 & 96 & -7778 \\
\hline & & & & & & & TD & 17049 & & -7874 \\
\hline \multirow[t]{3}{*}{13} & \multirow[t]{3}{*}{ Union Oil } & \multirow[t]{3}{*}{ Federal 1-G-24 } & \multirow{3}{*}{$\begin{array}{l}\text { SW } 1 / 4 N^{1} 1 / 4 \text { sec. } 24, \\
\text { T. } 11 \text { S., R. } 4 \text { E. }\end{array}$} & \multirow[t]{3}{*}{ Utah } & \multirow[t]{3}{*}{7451} & \multirow[t]{3}{*}{7404} & Indianola Group & 0 & 2245 & 7451 \\
\hline & & & & & & & Arapien Shale & 2245 & 5159 & 5206 \\
\hline & & & & & & & TD & 7404 & & 47 \\
\hline \multirow[t]{6}{*}{14} & \multirow[t]{6}{*}{ Union Oil } & \multirow[t]{6}{*}{ Federal 1-J-9 } & \multirow{6}{*}{$\begin{array}{l}\text { SW1/4NE } 1 / 4 \text { sec. } 9 \text {, } \\
\text { T. } 11 \text { S., R. } 4 \text { E. }\end{array}$} & \multirow[t]{6}{*}{ Utah } & \multirow[t]{6}{*}{6640} & \multirow[t]{6}{*}{6625} & North Horn Formation & 0 & 708 & 6640 \\
\hline & & & & & & & Indianola Group & 708 & 1064 & 5932 \\
\hline & & & & & & & Arapien Shale & 1772 & 3114 & 4868 \\
\hline & & & & & & & Twin Creek Limestone & 4886 & 584 & 1754 \\
\hline & & & & & & & Navajo Sandstone & 5470 & 1155 & 1170 \\
\hline & & & & & & & TD & 6625 & & 15 \\
\hline 15 & Phillips & Neilson-Seagar 1 & $\mathrm{SE}^{1 / 4} \mathrm{NE}^{1 / 4}$ sec. 1 , & Sanpete & 7542 & 9502 & Flagstaff Limestone & 0 & 475 & 7542 \\
\hline & & & T. 13 S., R. 2 E. & & & & North Horn Formation & 475 & 820 & 7067 \\
\hline & & & & & & & Sixmile Canyon Formation & 1295 & 8207 & 6247 \\
\hline & & & & & & & TD & 9502 & & -1960 \\
\hline 16 & Placid & WXC-Howard 1A & $\mathrm{NE}^{1 / 4 \mathrm{NW}^{1 / 4} / 4 \mathrm{sec} .5}$ & Juab & 5988 & 12150 & North Horn Formation & 0 & 3810 & 5988 \\
\hline & & & T. 14 S., R 1 W. & & & & Unnamed conglomerate & 3810 & 1078 & 2178 \\
\hline & & & & & & & Arapien Shale & 4888 & 4342 & 1100 \\
\hline & & & & & & & Twin Creek Limestone & 9230 & 1140 & -3242 \\
\hline & & & & & & & Gypsum Spring Member of Twin Creek Limestone & 10370 & 274 & -4382 \\
\hline & & & & & & & Navajo Sandstone & 10644 & 1450 & -4656 \\
\hline & & & & & & & Petrified Forest Member of Chinle Formation & 12094 & 56 & -6106 \\
\hline
\end{tabular}




\begin{tabular}{|c|c|c|c|c|c|c|c|c|c|c|}
\hline $\begin{array}{l}\text { Data } \\
\text { point }\end{array}$ & Operator & Well name & Location & County & $\begin{array}{l}\mathrm{KB} \\
\text { (ft) }\end{array}$ & $\begin{array}{l}\text { TD } \\
\text { (ft) } \\
\end{array}$ & Formation & $\begin{array}{l}\text { Top } \\
\text { (ft) }\end{array}$ & $\begin{array}{r}\text { Thickness } \\
\text { (ft) } \\
\end{array}$ & $\begin{array}{r}\text { Subsea } \\
\text { (ft) }\end{array}$ \\
\hline \multirow{8}{*}{17} & & & & & \multirow{8}{*}{6291} & & TD & 12150 & & -6162 \\
\hline & \multirow[t]{7}{*}{ Placid } & \multirow[t]{7}{*}{ WXC-Howard 2} & \multirow{7}{*}{$\begin{array}{l}\mathrm{NE}^{1 / 4} \mathrm{SE} E^{1 / 4} \text { sec. } 5 \text {, } \\
\text { T. } 14 \text { S., R. } 1 \text { W. }\end{array}$} & \multirow[t]{7}{*}{ Juab } & & \multirow[t]{7}{*}{10764} & North Horn Formation & 0 & 4078 & 6291 \\
\hline & & & & & & & Unnamed conglomerate & 4078 & 1099 & 2213 \\
\hline & & & & & & & Arapien Shale & 5177 & 4117 & 1114 \\
\hline & & & & & & & Twin Creek Limestone & 9294 & 1056 & -3003 \\
\hline & & & & & & & Gypsum Spring Member of Twin Creek Limestone & 10350 & 212 & -4059 \\
\hline & & & & & & & Navajo Sandstone & 10562 & 202 & -4271 \\
\hline & & & & & & & TD & 10764 & & -4473 \\
\hline \multirow[t]{15}{*}{18} & \multirow[t]{15}{*}{ Placid } & \multirow[t]{15}{*}{ WXC-State 1} & \multirow{15}{*}{$\begin{array}{l}\text { NW1/4SW1/4 sec. } 36 \\
\text { T. } 15 \text { S., R. 11/2 W. }\end{array}$} & \multirow[t]{15}{*}{ Juab } & \multirow[t]{15}{*}{5201} & \multirow[t]{15}{*}{13894} & Green River Formation & 0 & 796 & 5201 \\
\hline & & & & & & & Colton Formation & 796 & 414 & 4405 \\
\hline & & & & & & & Flagstaff Limestone & 1210 & 295 & 3991 \\
\hline & & & & & & & North Horn Formation & 1505 & 1840 & 3696 \\
\hline & & & & & & & Indianola Group & 3345 & 581 & 1856 \\
\hline & & & & & & & Unnamed conglomerate & 3926 & 922 & 1275 \\
\hline & & & & & & & Arapien Shale & 4848 & 1904 & 353 \\
\hline & & & & & & & Twin Creek Limestone & 6752 & 999 & -1551 \\
\hline & & & & & & & Gypsum Spring Member of Twin Creek Limestone & 7751 & 344 & -2550 \\
\hline & & & & & & & Thrust & 8095 & 0 & -2894 \\
\hline & & & & & & & Arapien Shale & 8095 & 3561 & -2894 \\
\hline & & & & & & & Twin Creek Limestone & 11656 & 919 & -6455 \\
\hline & & & & & & & Gypsum Spring Member of Twin Creek Limestone & 12575 & 344 & -7374 \\
\hline & & & & & & & Navajo Sandstone & 12919 & 975 & -7718 \\
\hline & & & & & & & TD & 13894 & & -8693 \\
\hline \multirow[t]{22}{*}{19} & \multirow{22}{*}{ Placid } & \multirow{22}{*}{ WXC-Barton 1} & \multirow{22}{*}{$\begin{array}{l}\text { NW1/4SE1/4 sec. } 32 \text {, } \\
\text { T. } 16 \text { S., R. } 1 \text { W. }\end{array}$} & \multirow{22}{*}{ Juab } & \multirow{22}{*}{5116} & \multirow[t]{22}{*}{21845} & Goldens Ranch Formation & 0 & 1641 & 5116 \\
\hline & & & & & & & Green River Formation & 1641 & 1076 & 3475 \\
\hline & & & & & & & Indianola Group & 2717 & 1733 & 2399 \\
\hline & & & & & & & Unnamed conglomerate & 4450 & 767 & 666 \\
\hline & & & & & & & Cedar Mountain Formation & 5217 & 205 & -101 \\
\hline & & & & & & & Twist Gulch Formation & 5422 & 308 & -306 \\
\hline & & & & & & & Arapien Shale & 5730 & 1820 & -614 \\
\hline & & & & & & & Twin Creak Limestone & 7550 & 560 & -2434 \\
\hline & & & & & & & Gypsum Spring Member of Twin Creek Limestone & 8110 & 162 & -2994 \\
\hline & & & & & & & Navajo Sandstone & 8272 & 1246 & -3156 \\
\hline & & & & & & & Petrified Forest Member of Chinle Formation & 9518 & 367 & -4402 \\
\hline & & & & & & & Moss Back Member of Chinle Formation & 9885 & 162 & -4769 \\
\hline & & & & & & & Moenkopi Formation & 10047 & 1638 & -4931 \\
\hline & & & & & & & Thrust & 11685 & 0 & -6569 \\
\hline & & & & & & & Paleozoic & 11685 & 1403 & -6569 \\
\hline & & & & & & & Thrust & 13088 & 0 & -7972 \\
\hline & & & & & & & Black Box Dolomite (inverted section) & 13088 & 235 & -7972 \\
\hline & & & & & & & Black Dragon Member of Moenkopi Formation (inverted) & 13323 & 287 & -8207 \\
\hline & & & & & & & Sinbad Limestone Member of Moenkopi Formation (inverted) & 13610 & 572 & -8494 \\
\hline & & & & & & & Middle Red Member of Moenkopi Formation (inverted) & 14182 & 408 & -9066 \\
\hline & & & & & & & Shnabkaib Member of Moenkopi Formation (inverted) & 14590 & 241 & -9474 \\
\hline & & & & & & & Upper Red Member of Moenkopi Formation (inverted) & 14831 & 299 & -9715 \\
\hline
\end{tabular}




\begin{tabular}{|c|c|c|c|c|c|c|c|c|c|c|}
\hline $\begin{array}{l}\text { Data } \\
\text { point }\end{array}$ & Operator & Well name & Location & County & $\begin{array}{l}\mathrm{KB} \\
\text { (ft) }\end{array}$ & $\begin{array}{l}\text { TD } \\
\text { (ft) }\end{array}$ & - Formation & $\begin{array}{l}\text { Top } \\
\text { (ft) } \\
\end{array}$ & $\begin{array}{r}\text { Thickness } \\
\text { (ft) }\end{array}$ & $\begin{array}{r}\text { Subsea } \\
\text { (ft) }\end{array}$ \\
\hline & & & & & & & Thrust & 15130 & 0 & -10014 \\
\hline & & & & & & & Sinbad Limestone Member of Moenkopi Formation & 15130 & 584 & -10014 \\
\hline & & & & & & & Thrust & 15714 & 0 & -10598 \\
\hline & & & & & & & Upper Red Member of Moenkopi Formation & 15714 & 346 & -10598 \\
\hline & & & & & & & Shnabkaib Member of Moenkopi Formation & 16060 & 260 & -10944 \\
\hline & & & & & & & Middle Red Member of Moenkopi Formation & 16320 & 310 & -11204 \\
\hline & & & & & & & Sinbad Limestone Member of Moenkopi Formation & 16630 & 565 & -11514 \\
\hline & & & & & & & Black Dragon Member of Moenkopi Formation & 17195 & 460 & -12079 \\
\hline & & & & & & & Black Box Dolomite & 17655 & 235 & -12539 \\
\hline & & & & & & & Toroweap Formation & 17890 & 1083 & -12774 \\
\hline & & & & & & & Humbug Formation & 18973 & 87 & -13857 \\
\hline & & & & & & & Deseret Limestone & 19060 & 920 & -13944 \\
\hline & & & & & & & Gardison Limestone & 19980 & 584 & -14864 \\
\hline & & & & & & & Fitchville Formation & 20564 & 246 & -15448 \\
\hline & & & & & & & Pinyon Peak Limestone & 20810 & 187 & -15694 \\
\hline & & & & & & & Cambrian(?) & 20997 & 848 & -15881 \\
\hline & & & & & & & TD & 21845 & & -16729 \\
\hline \multirow[t]{17}{*}{20} & Amoco & Sevier Bridge Unit 1 & $\mathrm{SW}^{1} / 4 \mathrm{SE}^{1 / 4} \mathrm{sec} .11$, & Juab & 5655 & 11000 & Green River Formation & 0 & 1280 & 5655 \\
\hline & & & T. 16 S., R. 1 W. & & & & Arapien Shale & 1280 & 3489 & 4375 \\
\hline & & & & & & & Twin Creek Limestone & 4769 & 421 & 886 \\
\hline & & & & & & & Gypsum Spring Member of Twin Creek Limestone & 5190 & 45 & 465 \\
\hline & & & & & & & Navajo Sandstone & 5235 & 1624 & 420 \\
\hline & & & & & & & Petrified Forest Member of Chinle Formation & 6859 & 611 & -1204 \\
\hline & & & & & & & Moss Back Member of Chinle Formation & 7470 & 130 & -1815 \\
\hline & & & & & & & Moenkopi Formation & 7600 & 390 & -1945 \\
\hline & & & & & & & Thrust & 7990 & 0 & -2335 \\
\hline & & & & & & & Navajo Sandstone & 7990 & 857 & -2335 \\
\hline & & & & & & & Petrified Forest Member of Chinle Formation & 8847 & 465 & -3192 \\
\hline & & & & & & & Moss Back Member of Chinle Formation & 9312 & 95 & -3657 \\
\hline & & & & & & & Upper Red Member of Moenkopi Formation & 9407 & 1054 & -3752 \\
\hline & & & & & & & Shnabkaib Member of Moenkopi Formation & 10461 & 217 & -4806 \\
\hline & & & & & & & Middle Red Member of Moenkopi Formation & 10678 & 310 & -5023 \\
\hline & & & & & & & Sinbad Limestone Member of Moenkopi Formation & 10988 & 12 & -5333 \\
\hline & & & & & & & TD & 11000 & & -5345 \\
\hline \multirow[t]{10}{*}{21} & Dixel & Gunnison State 1 & $\mathrm{NE}^{1} / 4 \mathrm{NE}^{1 / 4} \mathrm{sec} .15$, & Juab & 7918 & 15833 & Flagstaff Limestone & 0 & 1020 & 7918 \\
\hline & & & T. 16 S., R. 1 E. & & & & North Horn Formation & 1020 & 2204 & 6898 \\
\hline & & & & & & & Indianola Group & 3224 & 3487 & 4694 \\
\hline & & & & & & & Unnamed conglomerate & 6711 & 2033 & 1207 \\
\hline & & & & & & & Cedar Mountain Formation & 8744 & 862 & -826 \\
\hline & & & & & & & Twist Gulch Formation & 9606 & 1162 & -1688 \\
\hline & & & & & & & Arapien Shale & 10768 & 3668 & -2850 \\
\hline & & & & & & & Twin Creek Limestone & 14436 & 309 & -6518 \\
\hline & & & & & & & Navajo Sandstone & 14745 & 1088 & -6827 \\
\hline & & & & & & & TD & 15833 & & -7915 \\
\hline 22 & Mobil & Larson Unit 1 & SW1/4SE1/4 sec. 1, & Sanpete & 5434 & 14043 & Quaternary Alluvium & 0 & 680 & 5434 \\
\hline
\end{tabular}




\begin{tabular}{|c|c|c|c|c|c|c|c|c|c|c|}
\hline $\begin{array}{l}\text { Data } \\
\text { point }\end{array}$ & Operator & Well name & Location & County & $\begin{array}{l}\mathrm{KB} \\
\text { (ft) }\end{array}$ & $\begin{array}{l}\mathrm{TD} \\
\text { (ft) } \\
\end{array}$ & Formation & $\begin{array}{l}\text { Top } \\
\text { (ft) }\end{array}$ & $\begin{array}{r}\text { Thickness } \\
\text { (ft) }\end{array}$ & $\begin{array}{r}\text { Subsea } \\
\text { (ft) } \\
\end{array}$ \\
\hline \multirow{23}{*}{23} & \multirow{23}{*}{ Phillips } & \multirow{23}{*}{ Price N-1 } & \multirow[t]{10}{*}{ T. 17 S., R. 2 E. } & \multirow{23}{*}{ Sanpete } & \multirow{23}{*}{5498} & \multirow{23}{*}{12332} & Flagstaff Limestone (estimated top) & 680 & 270 & 4754 \\
\hline & & & & & & & North Horn Formation & 950 & 810 & 4484 \\
\hline & & & & & & & Funk Valley Formation & 1760 & 912 & 3674 \\
\hline & & & & & & & Allen Valley Shale & 2672 & 202 & 2762 \\
\hline & & & & & & & Sanpete Formation & 2874 & 466 & 2560 \\
\hline & & & & & & & Unnamed conglomerate & 3340 & 985 & 2094 \\
\hline & & & & & & & Cedar Mountain Formation & 4325 & 1686 & 1109 \\
\hline & & & & & & & Twist Gulch Formation & 6011 & 1595 & -577 \\
\hline & & & & & & & Arapien Shale & 7606 & 6437 & -2172 \\
\hline & & & & & & & TD & 14043 & & -8609 \\
\hline & & & \multirow{13}{*}{$\begin{array}{l}\mathrm{SE}^{1 / 4} \mathrm{SE} \mathrm{E}^{1 / 4} \mathrm{sec} .29 \\
\text { T. } 15 \text { S., R. } 3 \text { E. }\end{array}$} & & & & Quaternary Alluvium & 0 & 465 & 5498 \\
\hline & & & & & & & Green River Formation (estimated top) & 465 & 1123 & 5033 \\
\hline & & & & & & & Colton Formation & 1588 & 392 & 3910 \\
\hline & & & & & & & Flagstaff Limestone & 1980 & 200 & 3518 \\
\hline & & & & & & & North Horn Formation & 2180 & 1330 & 3318 \\
\hline & & & & & & & Funk Valley Formation & 3510 & 925 & 1988 \\
\hline & & & & & & & Allen Valley Shale & 4435 & 397 & 1063 \\
\hline & & & & & & & Sanpete Formation & 4832 & 821 & 666 \\
\hline & & & & & & & Unnamed conglomerate & 5653 & 702 & -155 \\
\hline & & & & & & & Cedar Mountain Formation & 6355 & 670 & -857 \\
\hline & & & & & & & Twist Gulch Formation & 7025 & 1545 & -1527 \\
\hline & & & & & & & Arapien Shale & 8570 & 3762 & -3072 \\
\hline & & & & & & & TD & 12332 & & -6834 \\
\hline \multirow[t]{10}{*}{24} & \multirow[t]{10}{*}{ Tennesse Gas } & \multirow[t]{10}{*}{ Irons 1} & \multirow{10}{*}{ 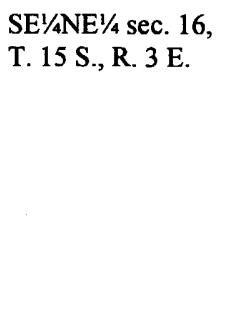 } & \multirow[t]{10}{*}{ Sanpete } & \multirow[t]{10}{*}{5527} & \multirow[t]{10}{*}{9995} & Quaternary Alluvium & 0 & 465 & 5527 \\
\hline & & & & & & & Green River Formation (estimated top) & 465 & 1625 & 5062 \\
\hline & & & & & & & Colton Formation & 2090 & 415 & 3437 \\
\hline & & & & & & & Flagstaff Limestone & 2505 & 225 & 3022 \\
\hline & & & & & & & North Horn Formation & 2730 & 2815 & 2797 \\
\hline & & & & & & & Sixmile Canyon Formation & 5545 & 1005 & -18 \\
\hline & & & & & & & Funk Valley Formation & 6550 & 2655 & -1023 \\
\hline & & & & & & & Allen Valley Shale & 9205 & 535 & -3678 \\
\hline & & & & & & & Sanpete Formation & 9740 & 255 & -4213 \\
\hline & & & & & & & TD & 9995 & & -4468 \\
\hline \multirow[t]{12}{*}{25} & \multirow[t]{12}{*}{ Hanson Oil } & \multirow[t]{12}{*}{ Moroni $1 \mathrm{AX}$} & \multirow{12}{*}{ 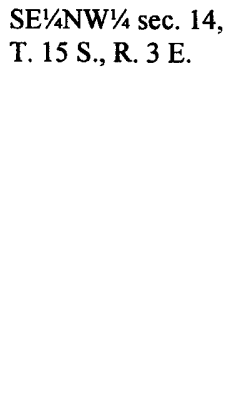 } & \multirow[t]{12}{*}{ Sanpete } & \multirow[t]{12}{*}{5708} & 21264 & Crazy Hollow Formation & 0 & 300 & 5708 \\
\hline & & & & & & & Green River Formation (estimated top) & 300 & 1355 & 5408 \\
\hline & & & & & & & Colton Formation & 1655 & 425 & 4053 \\
\hline & & & & & & & Flagstaff Limestone & 2080 & 220 & 3628 \\
\hline & & & & & & & North Horn Formation & 2300 & 2780 & 3408 \\
\hline & & & & & & & Sixmile Canyon Formation & 5080 & 3990 & 628 \\
\hline & & & & & & & Funk Valley Formation & 9070 & 2480 & -3362 \\
\hline & & & & & & & Allen Valley Shale & 11550 & 520 & -5842 \\
\hline & & & & & & & Sanpete Formation & 12070 & 302 & -6362 \\
\hline & & & & & & & Unnamed conglomerate & 12372 & 733 & -6664 \\
\hline & & & & & & & Cedar Mountain Formation & 13105 & 595 & -7397 \\
\hline & & & & & & & Twist Gulch Formation & 13700 & 873 & -7992 \\
\hline
\end{tabular}




\begin{tabular}{|c|c|c|c|c|c|c|c|c|c|c|}
\hline $\begin{array}{l}\text { Data } \\
\text { point } \\
\end{array}$ & Operator & Well name & Location & County & $\begin{array}{l}\text { KB } \\
\text { (ft) }\end{array}$ & $\begin{array}{l}\text { TD } \\
\text { (ft) }\end{array}$ & Formation & $\begin{array}{l}\text { Top } \\
\text { (ft) }\end{array}$ & $\begin{array}{r}\text { Thickness } \\
(\mathrm{ft})\end{array}$ & $\begin{array}{r}\begin{array}{r}\text { Subsea } \\
(\mathrm{ft})\end{array} \\
\end{array}$ \\
\hline 26 & Phillips & USA-E 1 & $\begin{array}{l}\mathrm{NW}^{1 / 4 \mathrm{NE}^{1 / 4} / 4 \mathrm{sec} .} 27 \text {, } \\
\text { T. } 19 \text { S., R. } 3 \text { E. }\end{array}$ & Sanpete & 8031 & 20450 & $\begin{array}{l}\text { Arapien Shale } \\
\text { Twin Creek Limestone } \\
\text { Navajo Sandstone } \\
\text { Petrified Forest Member of Chinle Formation } \\
\text { Moss Back Member of Chinle Formation } \\
\text { Upper Red Member of Moenkopi Formation } \\
\text { Shnabkaib Member of Moenkopi Formation } \\
\text { Middle Red Member of Moenkopi Formation } \\
\text { Sinbad Limestone Member of Moenkopi Formation } \\
\text { Black Dragon Member of Moenkopi Formation } \\
\text { Black Box Dolomite } \\
\text { Toroweap Formation } \\
\text { TD } \\
\text { North Horn Formation } \\
\text { Price River Formation } \\
\text { Castlegate Sandstone } \\
\text { Blackhawk Formation } \\
\text { Star Point Sandstone } \\
\text { Upper Part Blue Gate Member of Mancos Shale } \\
\text { Emery Sandstone Member of Mancos Shale } \\
\text { Lower Part Blue Gate Member of Mancos Shale } \\
\text { Ferron Sandstone Member of Mancos Shale } \\
\text { Tununk Member of Mancos Shale } \\
\text { Dakota Sandstone } \\
\text { Unnamed conglomerate } \\
\text { Cedar Mountain Formation } \\
\text { Summerville Formation } \\
\text { Curtis Formation } \\
\text { Twist Gulch Formation } \\
\text { Arapien Shale } \\
\text { Twin Creek Limestone } \\
\text { Navajo Sandstone } \\
\text { Kayenta Formation } \\
\text { Wingate Sandstone } \\
\text { Petrified Forest Member of Chinle Formation } \\
\text { Moss Back Member of Chinle Formation } \\
\text { Upper Red Member of Moenkopi Formation } \\
\text { Shnabkaib Member of Moenkopi Formation } \\
\text { Middle Red Member of Moenkopi Formation } \\
\text { Sinbad Limestone Member of Moenkopi Formation } \\
\text { Black Dragon Member of Moenkopi Formation } \\
\text { Black Box Dolomite } \\
\text { Toroweap Formation } \\
\text { Redwall Limestone } \\
\text { Ouray Limestone }\end{array}$ & $\begin{array}{r}14573 \\
17310 \\
17850 \\
18535 \\
18560 \\
18630 \\
19345 \\
19572 \\
19829 \\
20073 \\
20500 \\
20840 \\
21264 \\
0 \\
1205 \\
2156 \\
2563 \\
3505 \\
4159 \\
4555 \\
6690 \\
8092 \\
8804 \\
9383 \\
10053 \\
10272 \\
10962 \\
11517 \\
11689 \\
12193 \\
13161 \\
13731 \\
14350 \\
14620 \\
14950 \\
15250 \\
15328 \\
15942 \\
16027 \\
16250 \\
16488 \\
16795 \\
16978 \\
17457 \\
18212\end{array}$ & $\begin{array}{r}2737 \\
540 \\
685 \\
25 \\
70 \\
715 \\
227 \\
257 \\
244 \\
427 \\
340 \\
424 \\
\\
1205 \\
951 \\
407 \\
942 \\
654 \\
396 \\
2135 \\
1402 \\
712 \\
579 \\
670 \\
219 \\
690 \\
555 \\
172 \\
504 \\
968 \\
570 \\
619 \\
270 \\
330 \\
300 \\
78 \\
614 \\
85 \\
223 \\
238 \\
307 \\
183 \\
479 \\
755 \\
116\end{array}$ & $\begin{array}{r}-8865 \\
-11602 \\
-12142 \\
-12827 \\
-12852 \\
-12922 \\
-13637 \\
-13864 \\
-14121 \\
-14365 \\
-14792 \\
-15132 \\
-15556 \\
8031 \\
6826 \\
5875 \\
5468 \\
4526 \\
3872 \\
3476 \\
1341 \\
-61 \\
-773 \\
-1352 \\
-2022 \\
-2241 \\
-2931 \\
-3486 \\
-3658 \\
-4162 \\
-5130 \\
-5700 \\
-6319 \\
-6589 \\
-6919 \\
-7219 \\
-7297 \\
-7911 \\
-7996 \\
-8219 \\
-8457 \\
-8764 \\
-8947 \\
-9426 \\
-10181\end{array}$ \\
\hline
\end{tabular}




\begin{tabular}{|c|c|c|c|c|c|c|c|c|c|c|}
\hline $\begin{array}{l}\text { Data } \\
\text { point }\end{array}$ & Operator & Well name & Location & County & $\begin{array}{l}\mathrm{KB} \\
(\mathrm{ft})\end{array}$ & $\begin{array}{l}\text { TD } \\
\text { (ft) }\end{array}$ & Formation & $\begin{array}{l}\text { Top } \\
\text { (ft) }\end{array}$ & $\begin{array}{r}\text { Thickness } \\
\text { (ft) }\end{array}$ & $\begin{array}{r}\text { Subsea } \\
(\mathrm{ft})\end{array}$ \\
\hline & & & & & & & $\begin{array}{l}\text { Elbert Formation } \\
\text { Lynch Dolomite } \\
\text { Maxfield Limestone } \\
\text { Ophir Shale } \\
\text { Tintic Quartzite } \\
\text { TD }\end{array}$ & $\begin{array}{l}18328 \\
18777 \\
19416 \\
20093 \\
20324 \\
20450\end{array}$ & $\begin{array}{l}449 \\
639 \\
677 \\
231 \\
126\end{array}$ & $\begin{array}{l}-10297 \\
-10746 \\
-11385 \\
-12062 \\
-12293 \\
-12419\end{array}$ \\
\hline 27 & $\begin{array}{l}\text { Surface control } \\
\text { I-1631 }\end{array}$ & $\begin{array}{l}\text { USGS Miscellaneous } \\
\text { Investigations Map I-1631 }\end{array}$ & & & & & & & & \\
\hline 28 & BWAB & Orangeville Unit 1 & $\begin{array}{l}\mathrm{NW}^{1 / 4} \mathrm{NW} 1 / 4 \text { sec. } 1, \\
\text { T. } 19 \text { S., R. } 7 \text { E. }\end{array}$ & Emery & 6119 & 8560 & $\begin{array}{l}\text { Blue Gate Member of Mancos Shale } \\
\text { Ferron Sandstone Member of Mancos Shale } \\
\text { Tununk Member of Mancos Shale } \\
\text { Dakota Sandstone } \\
\text { Cedar Mountain Formation } \\
\text { Morrison Formation } \\
\text { Summerville Formation } \\
\text { Curtis Formation } \\
\text { Entrada Sandstone } \\
\text { Carmel Formation (Upper) } \\
\text { Carmel Formation (Lower) } \\
\text { Navajo Sandstone } \\
\text { Kayenta Formation } \\
\text { Wingate Sandstone } \\
\text { Petrified Forest Member of Chinle Formation } \\
\text { Moss Back Member Chinle Formation } \\
\text { Moody Canyon Member of Moenkopi Formation } \\
\text { Torrey Member of Moenkopi Formation } \\
\text { Sinbad Limestone Member of Moenkopi Formation } \\
\text { Black Dragon Member of Moenkopi Formation } \\
\text { Black Box Dolomite } \\
\text { White Rim Sandstone } \\
\text { TD }\end{array}$ & $\begin{array}{r}0 \\
2184 \\
2490 \\
3076 \\
3096 \\
3589 \\
4007 \\
4357 \\
4530 \\
5210 \\
5800 \\
6059 \\
6546 \\
6708 \\
7052 \\
7150 \\
7230 \\
7639 \\
7980 \\
8111 \\
8350 \\
8484 \\
8560\end{array}$ & $\begin{array}{r}2184 \\
306 \\
586 \\
20 \\
493 \\
418 \\
350 \\
173 \\
680 \\
590 \\
259 \\
487 \\
162 \\
344 \\
98 \\
80 \\
409 \\
341 \\
131 \\
239 \\
134 \\
76\end{array}$ & $\begin{array}{r}6119 \\
3935 \\
3629 \\
3043 \\
3023 \\
2530 \\
2112 \\
1762 \\
1589 \\
909 \\
319 \\
60 \\
-427 \\
-589 \\
-933 \\
-1031 \\
-1111 \\
-1520 \\
-1861 \\
-1992 \\
-2231 \\
-2365 \\
-2441\end{array}$ \\
\hline 29 & Pan American & Ferron Unit 3 & $\begin{array}{l}\mathrm{SE}^{1 / 4 N W} \mathrm{~N} / 4 \text { sec. } 21 \text {, } \\
\text { T. } 20 \text { S., R. } 7 \text { E. }\end{array}$ & Emery & 5948 & 10022 & $\begin{array}{l}\text { Blue Gate Member of Mancos Shale } \\
\text { Ferron Sandstone Member of Mancos Shale } \\
\text { Tununk Member of Mancos Shale } \\
\text { Dakota Sandstone } \\
\text { Cedar Mountain Formation } \\
\text { Morrison Formation } \\
\text { Summerville Formation } \\
\text { Curtis Formation } \\
\text { Entrada Sandstone } \\
\text { Carmel Formation (Upper) } \\
\text { Carmel Formation (Lower) } \\
\text { Navajo Sandstone } \\
\text { Kayenta Formation } \\
\text { Wingate Sandstone }\end{array}$ & $\begin{array}{r}0 \\
798 \\
1110 \\
1678 \\
1740 \\
2185 \\
2489 \\
2895 \\
2985 \\
3785 \\
4282 \\
4805 \\
5415 \\
5625\end{array}$ & $\begin{array}{r}798 \\
312 \\
568 \\
62 \\
445 \\
304 \\
406 \\
90 \\
800 \\
497 \\
523 \\
610 \\
210 \\
267\end{array}$ & $\begin{array}{r}5948 \\
5150 \\
4838 \\
4270 \\
4208 \\
3763 \\
3459 \\
3053 \\
2963 \\
2163 \\
1666 \\
1143 \\
533 \\
323\end{array}$ \\
\hline
\end{tabular}


